\title{
Increased soil organic carbon stocks under agroforestry: a survey of six different sites in
}

\section{France}

Rémi Cardinael ${ }^{\mathrm{a}, \mathrm{b}, \mathrm{c}}$, Tiphaine Chevallier ${ }^{\mathrm{a} *}$, Aurélie Cambou ${ }^{\mathrm{a}, \mathrm{d}}$, Camille Béral $^{\mathrm{e}}$, Bernard G. Barthès $^{\mathrm{a}}$, Christian Dupraz ${ }^{\mathrm{f}}$, Céline Durand ${ }^{\mathrm{a}}$, Ernest Kouakoua ${ }^{\mathrm{a}}$, Claire Chenu ${ }^{\mathrm{b}}$

${ }^{\text {a }}$ IRD, UMR Eco\&Sols, Montpellier SupAgro, 2 place Viala, 34060 Montpellier, France

${ }^{\mathrm{b}}$ AgroParisTech, UMR Ecosys, Avenue Lucien Brétignières, 78850 Thiverval-Grignon, France

${ }^{\mathrm{c}}$ CIRAD, UPR AIDA, Avenue d'Agropolis, 34398 Montpellier, France (present address)

d AgroCampus Ouest centre d'Angers, UPSP EPHor, 2 Rue André le Nôtre, 49045 Angers, France (present address)

e Agroof, 9 plan de Brie, 30140 Anduze, France

${ }^{\mathrm{f}}$ INRA, UMR System, Montpellier SupAgro, 2 place Viala, 34060 Montpellier, France

* Corresponding author. Tel.: +33 04.67.61.53.08. E-mail address: remi.cardinael@cirad.fr

\section{ABSTRACT}

Agroforestry systems are land use management systems in which trees are grown in combination with crops or pasture in the same field. In silvoarable systems, trees are intercropped with arable crops, and in silvopastoral systems trees are combined with pasture for livestock. These systems may produce forage and timber as well as providing ecosystem services such as climate change mitigation. Carbon (C) is stored in the aboveground and belowground biomass of the trees, and the transfer of organic matter from the trees to the soil can increase soil organic carbon (SOC) stocks. Few studies have assessed the impact of agroforestry systems on carbon storage in soils in temperate climates, as most have been 
undertaken in tropical regions. This study assessed five silvoarable systems and one silvopastoral system in France. All sites had an agroforestry system with an adjacent, purely agricultural control plot. The land use management in the inter-rows in the agroforestry systems and in the control plots were identical. The age of the study sites ranged from 6 to 41 years after tree planting. Depending on the type of soil, the sampling depth ranged from 20 to $100 \mathrm{~cm}$ and SOC stocks were assessed using equivalent soil masses. The aboveground biomass of the trees was also measured at all sites. In the silvoarable systems, the mean organic carbon stock accumulation rate in the soil was $0.24(0.09-0.46) \mathrm{Mg} \mathrm{C} \mathrm{ha}^{-1} \mathrm{yr}^{-1}$ at a depth of $30 \mathrm{~cm}$ and 0.65 (0.004-1.85) $\mathrm{Mg} \mathrm{C} \mathrm{ha}^{-1} \mathrm{yr}^{-1}$ in the tree biomass. Increased SOC stocks were also found in deeper soil layers at two silvoarable sites. Young plantations stored additional SOC but mainly in the soil under the rows of trees, possibly as a result of the herbaceous vegetation growing in the rows. At the silvopastoral site, the SOC stock was significantly greater at a depth of 30 to 50 $\mathrm{cm}$ than in the control. Overall, this study showed the potential of agroforestry systems to store $\mathrm{C}$ in both soil and biomass in temperate regions.

Keywords: Alley cropping, Soil organic carbon storage, Equivalent soil mass, Aboveground biomass, Belowground biomass

\section{Introduction}

Soils play an essential role in the global carbon budget (Houghton, 2007). Currently, the land sink (including soil and vegetation) absorbs about $30 \%$ of the carbon $(\mathrm{C})$ emitted to the atmosphere through the burning of fossil fuel and cement production (Le Quéré et al., 2014). Since 1850, the depletion of soil organic carbon (SOC) in cultivated lands has transferred about 
$70 \mathrm{Gt}$ C to the atmosphere (Amundson, 2001; Lal, 2004a). The potential of these SOC depleted soils as future $\mathrm{C}$ sinks through SOC sequestration has now been recognized (Paustian et al., 1997; Freibauer et al., 2004; Smith, 2004). In France, SOC stocks have been estimated at 3.13.3 Gt C in the top $30 \mathrm{~cm}$ of soils (Arrouays et al., 2001; Martin et al., 2011). Based on the SOC saturation capacity (Hassink, 1997), assuming that the quantity of stable SOC is limited by the amount of fine particles, Angers et al. (2011) found that the median saturation deficit of French arable topsoils was $8.1 \mathrm{~g} \mathrm{C} \mathrm{kg}^{-1}$ soil. About $70 \%$ of French agricultural topsoils are, therefore, unsaturated in SOC and have the potential for additional SOC storage. Increasing SOC stocks is often seen as a win-win strategy (Lal, 2004a; Janzen, 2006) as it allows the transfer of $\mathrm{CO}_{2}$ from the atmosphere to the soil while improving soil quality and fertility (Lal, 2004b).

Several agricultural practices have been developed to increase SOC stocks. For instance, the introduction of cover crops (Constantin et al., 2010; Poeplau and Don, 2015) or grasslands (Conant et al., 2001; Soussana et al., 2004) in the cropping sequence has proven effective. The effect of no-till farming on SOC stocks is disputed and highly variable (Luo et al., 2010; Virto et al., 2012; Dimassi et al., 2013) and seems to depend on the amount of C transferred from the crops to the soil (Virto et al., 2012). Agroforestry is a general term for agroecosystems in which trees are intercropped with crops or pasture (Nair, 1993). Silvoarable systems intercrop trees and arable crops and silvopastoral systems combine trees, pasture and livestock. These are recognized as possible land use management systems that can maintain or increase SOC stocks, both in tropical (Albrecht and Kandji, 2003) and temperate regions (Peichl et al., 2006; Bambrick et al., 2010; Wotherspoon et al., 2014). However, most studies only consider the surface soil layers (to a depth of $<20$ or $30 \mathrm{~cm}$ ) whereas trees grown in agroforestry can be very deep rooted (Mulia and Dupraz, 2006; Cardinael et al., 2015a) and affect deep SOC stocks. A recent study in the Mediterranean region of France showed that an 18-year-old silvoarable system with hybrid walnuts intercropped with durum wheat increased SOC stocks by $0.25 \pm$ 
$0.03 \mathrm{Mg} \mathrm{C} \mathrm{ha}^{-1} \mathrm{yr}^{-1}$ in the $0-30 \mathrm{~cm}$ layer and by $0.35 \pm 0.04 \mathrm{Mg} \mathrm{C} \mathrm{ha}^{-1} \mathrm{yr}^{-1}$ from 0 to $100 \mathrm{~cm}$ compared to an adjacent agricultural plot (Cardinael et al., 2015b). Furthermore, although trees affect the spatial distribution of organic matter inputs to the soil (Rhoades, 1997), sampling protocols have not always taken account of the potential impact on the spatial distribution of SOC stocks. Some authors showed that SOC stocks were greater in the tree rows than in the inter-rows, and found no gradients within the inter-rows (Peichl et al., 2006; Upson and Burgess, 2013). Bambrick et al., (2010) found that the spatial distribution of SOC stocks varied with the time after tree planting. Few studies have estimated SOC storage in agroforestry systems in temperate conditions (Howlett et al., 2011; Mosquera Losada et al., 2011; Upson and Burgess, 2013) and these studies sometimes do not have control plots without trees for comparison, making it difficult to evaluate the precise effect of agroforestry on SOC stocks (Pellerin et al., 2013).

This study set out i) to quantify organic carbon stocks in soils and in the tree biomass in six agroforestry systems with adjacent agricultural control plots under different soil and climate conditions in France, ii) to study the spatial distribution of SOC stocks as a function of the distance from individual trees and the tree rows and iii) to estimate the SOC stock accumulation rates for these agroforestry systems.

\section{Materials and methods}

\subsection{The six agroforestry sites}

Each study site had an agroforestry system and an adjacent agricultural control plot. Before tree planting, the agroforestry plot was part of the agricultural plot, with the same soil use and management (crop rotation, fertilization, soil tillage). After tree planting, the soil management of the agroforestry inter-rows and of the agricultural plot remained identical. Rows of trees 
were planted in the agroforestry fields, with natural or sown grasses between the trees. Five sites, Restinclières (RE), Châteaudun (CH), Melle (ME), Saint-Jean d'Angely (SJ), and Vézénobres (VE), were silvoarable systems with no grazing. Only one site, Theix (TH), was a silvopastoral system with regular grazing. Four sites were owned and managed by farmers and Restinclières (RE) and Theix (TH) were experimental research sites.

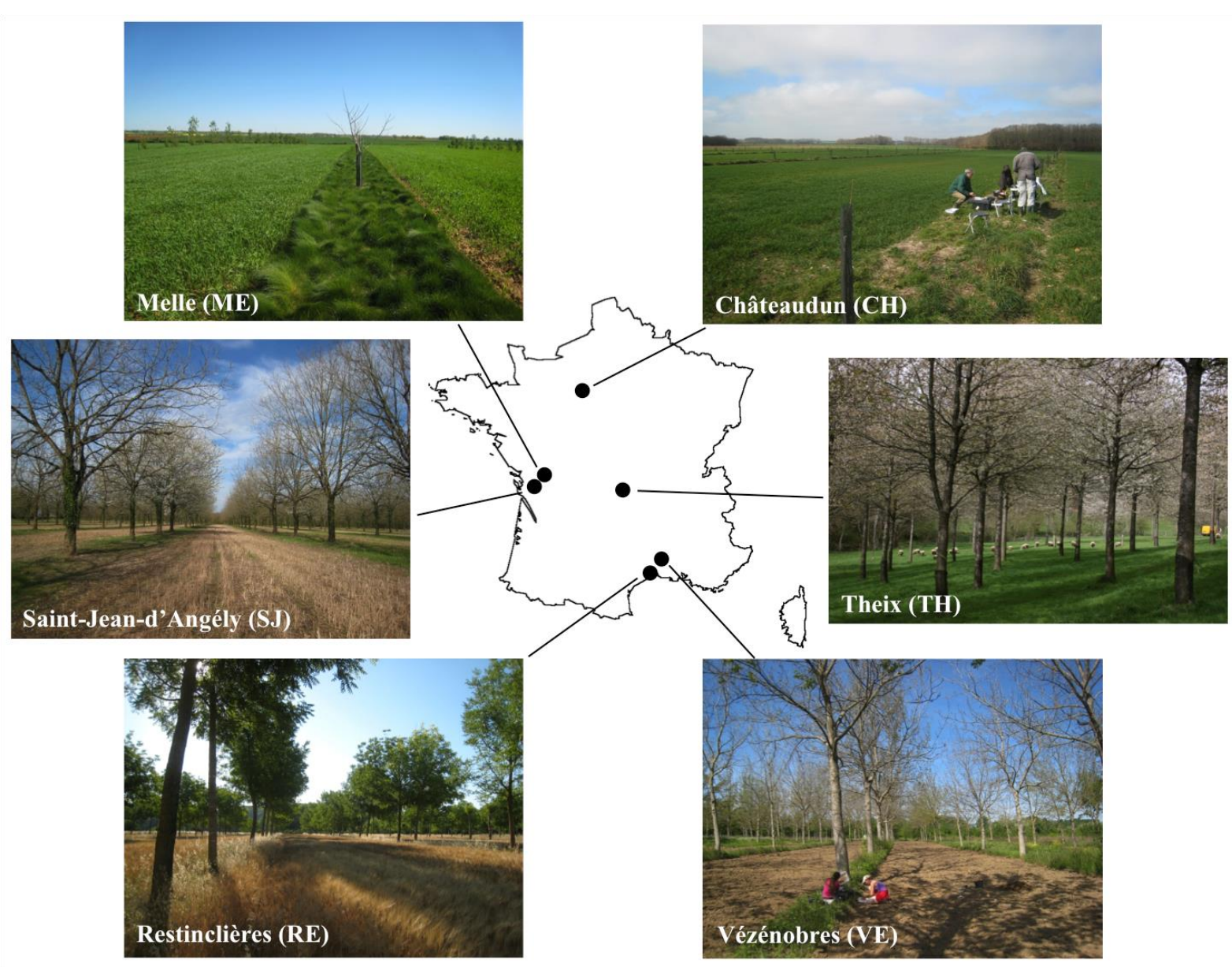

Figure 1. Location and description of the six study cases under agroforestry systems sampled in France. 
109

\begin{tabular}{|c|c|c|c|c|c|c|c|}
\hline \multirow[t]{2}{*}{ Site } & \multirow[t]{2}{*}{$\begin{array}{l}\text { Mean annual temperature } \\
\left({ }^{\circ} \mathrm{C}\right)\end{array}$} & \multirow[t]{2}{*}{$\begin{array}{l}\text { Mean annual rainfall } \\
(\mathrm{mm})\end{array}$} & \multirow[t]{2}{*}{$\begin{array}{l}\text { Soil type } \\
\text { (FAO) }\end{array}$} & \multirow[t]{2}{*}{$\begin{array}{l}\text { Soil depth } \\
\quad(\mathrm{cm})\end{array}$} & \multicolumn{2}{|c|}{$\begin{array}{c}\text { Soil texture } \\
\text { clay/silt/sand }\left(\mathrm{g} \mathrm{kg}^{-1}\right)\end{array}$} & \multirow[t]{2}{*}{$\begin{array}{l}\text { Soil pH } \\
\text { in water }\end{array}$} \\
\hline & & & & & Agroforestry & Control & \\
\hline $\mathrm{CH}$ & 11.1 & 595 & Luvisol & $0-30$ & $200 / 700 / 100$ & 190/710/100 & 7.0 \\
\hline $\mathrm{ME}$ & 11.7 & 810 & Luvisol & $0-30$ & $240 / 660 / 100$ & $260 / 630 / 110$ & 5.8 \\
\hline SJ & 12.9 & 850 & Luvisol & $0-20$ & $560 / 370 / 70$ & $500 / 410 / 90$ & 7.7 \\
\hline \multirow[t]{2}{*}{$\mathrm{VE}$} & 14.5 & 1037 & Fluvisol & $0-30$ & $110 / 410 / 480$ & $90 / 370 / 540$ & 8.3 \\
\hline & & & & $30-60$ & $100 / 440 / 460$ & $80 / 370 / 550$ & 8.3 \\
\hline \multirow[t]{4}{*}{$\mathrm{RE}$} & 15.4 & 873 & Fluvisol & $0-30$ & $173 / 406 / 421$ & $176 / 413 / 411$ & 8.0 \\
\hline & & & & $30-50$ & $178 / 416 / 406$ & $177 / 421 / 402$ & 8.1 \\
\hline & & & & $50-70$ & $250 / 501 / 249$ & $243 / 507 / 250$ & 8.2 \\
\hline & & & & $70-100$ & $309 / 582 / 109$ & $307 / 586 / 107$ & 8.3 \\
\hline \multirow[t]{2}{*}{$\mathrm{TH}$} & 7.7 & 800 & Andosol & $0-20$ & $340 / 300 / 360$ & $380 / 360 / 260$ & 6.5 \\
\hline & & & & $20-50$ & $320 / 280 / 400$ & $360 / 380 / 260$ & 6.5 \\
\hline
\end{tabular}

Table 1 Site characteristics. 
Table 2 Description of the agroforestry plots.

\begin{tabular}{|c|c|c|c|c|c|c|c|c|}
\hline Site & Tree species & $\begin{array}{l}\text { Age } \\
\text { (yrs) }\end{array}$ & $\begin{array}{c}\text { Density } \\
\left(\text { trees ha }^{-1}\right)\end{array}$ & $\begin{array}{l}\text { Distance between } \\
\text { trees in tree rows } \\
(\mathrm{m})\end{array}$ & $\begin{array}{l}\text { Width of } \\
\text { inter-rows } \\
(\mathrm{m})\end{array}$ & $\begin{array}{l}\text { Width of } \\
\text { tree rows } \\
(\mathrm{m})\end{array}$ & $\begin{array}{c}\text { Area occupied by tree } \\
\text { rows in the AF plot } \\
(\%)\end{array}$ & Crops \\
\hline $\mathrm{CH}$ & Hybrid walnut & 6 & 34 & 10 & 24 & 2 & 8 & wheat, rapeseed \\
\hline ME & Hybrid walnut & 6 & 35 & 8 & 27 & 2 & 7 & $\begin{array}{c}\text { wheat, rapeseed, } \\
\text { sunflower }\end{array}$ \\
\hline SJ & Black walnut & 41 & 102 & 7 & 12 & 2 & 14 & $\begin{array}{l}\text { sunflower, wheat, } \\
\text { barley }\end{array}$ \\
\hline VE & Hybrid walnut & 18 & 100 & 10 & 9 & 2 & 18 & $\begin{array}{l}\text { rapeseed, wheat, } \\
\text { potato, garlic }\end{array}$ \\
\hline $\mathrm{RE}$ & Hybrid walnut & 18 & 110 & $4-12$ & 11 & 2 & 16 & $\begin{array}{l}\text { durum wheat, } \\
\text { rapeseed, } \\
\text { chickpea }\end{array}$ \\
\hline TH & Wild cherry & 26 & 200 & 7 & No row & No row & No row & ryegrass, fescue \\
\hline
\end{tabular}

114 CH: Châteaudun, ME: Melle, SJ: Saint-Jean-d'Angély, VE: Vézénobres, RE: Restinclières, TH: Theix. 
The CH silvoarable site was located in Châteaudun (Fig. 1), in the department of Eure-et-Loir (longitude $1^{\circ} 17^{\prime} 58^{\prime}$ ' E, latitude $48^{\circ} 06^{\prime} 08^{\prime}$ ' $\mathrm{N}$, elevation $147 \mathrm{~m}$ a.s.l.). The mean temperature was $11.1^{\circ} \mathrm{C}$ and the mean annual rainfall $595 \mathrm{~mm}$ (years 2001-2013, INRA CLIMATIK, https://intranet.inra.fr/climatik). The soil was a silty loam Luvisol (IUSS Working Group WRB, 2007) (Table 1). Hybrid walnut trees (Juglans regia $\times$ nigra cv. NG23) were planted in February 2008 at a density of 34 trees ha- ${ }^{-1}$. The trees were planted $10 \mathrm{~m}$ apart within the rows, with $26 \mathrm{~m}$ between rows. A mix of ryegrass (Lolium perenne L.) and tall fescue (Festuca arundinacea Schreb.) was sown in August 2007 in two meter wide strips along the tree rows before the trees were planted. After tree planting, wheat (Triticum aestivum L. subsp. aestivum) and rapeseed (Brassica napus L.) were grown in rotation in the control plot and in the interrows (Table 2). The mean fresh grain yield was 7.5-8 $\mathrm{tha}^{-1}$ for wheat, and $3.8 \mathrm{t} \mathrm{ha}^{-1}$ for rapeseed. All crop residues were left in the field after harvest. The agroforestry inter-rows and the control plot were ploughed every three years to a depth of $22 \mathrm{~cm}$ and harrowed to $8 \mathrm{~cm}$ the other years.

The ME silvoarable site was located in Melle (Fig. 1), in the department of Deux-Sèvres (longitude $0^{\circ} 10^{\prime} 37^{\prime}, \mathrm{W}$, latitude $46^{\circ} 11^{\prime} 54^{\prime}$ ' $\mathrm{N}$, elevation $107 \mathrm{~m}$ a.s.l.). The mean temperature was $11.7^{\circ} \mathrm{C}$ and the mean annual rainfall $810 \mathrm{~mm}$ (years 1990-2013, INRA CLIMATIK, https://intranet.inra.fr/climatik). The soil was a silty loam Luvisol (IUSS Working Group WRB, 2007) (Table 1). Hybrid walnut trees (Juglans regia $\times$ nigra cv. NG23) were planted in 2008 at a density of 35 trees ha $^{-1}$. The trees were planted $8 \mathrm{~m}$ apart within the rows, with $29 \mathrm{~m}$ between rows. Sheep fescue (Festuca ovina L.) was sown in 2008 in two meter wide strips along the tree rows before the trees were planted. After tree planting, wheat (Triticum aestivum L. subsp. aestivum), rapeseed (Brassica napus L.) and sunflower (Helianthus annuus L.) were grown in rotation in the control plot and in the inter-rows (Table 2). The mean fresh grain yield was 8$8.5 \mathrm{t} \mathrm{ha}^{-1}$ for wheat, $3.3 \mathrm{tha}^{-1}$ for rapeseed and $2.5 \mathrm{t} \mathrm{ha}^{-1}$ for sunflower. Crop residues were usually exported, but this was counterbalanced by the application of manure in both the 
agroforestry inter-rows and the control plot (the farmer was unable to specify the application rates, but they were similar for both plots). Before the spring crop (sunflower), a winter cover crop was sown to prevent soil erosion and nitrate leaching. This cover crop was a mix of radish (Raphanus sativus L.), phacelia (Phacelia tanacetifolia Benth.) and mustard (Sinapis alba L.). The soil was ploughed every year to a depth of $20 \mathrm{~cm}$ in both the agroforestry inter-rows and the control plot. The agroforestry system was established on a moderate slope, while the control plot was flat.

The SJ silvoarable site was located in Saint-Jean-d'Angély (Fig. 1), in the department of

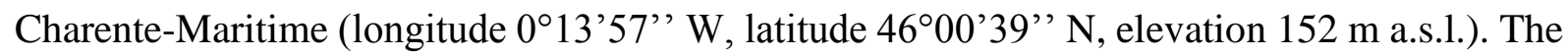
mean temperature was $12.9^{\circ} \mathrm{C}$ and the mean annual rainfall $850 \mathrm{~mm}$ (years 1990-2013, INRA CLIMATIK, https://intranet.inra.fr/climatik). The soil was a carbonated silty clay Luvisol (IUSS Working Group WRB, 2007) (Table 1). Black walnut trees (Juglans nigra L.) were planted in 1973 at a density of 102 trees ha ${ }^{-1}$. The trees were planted $7 \mathrm{~m}$ apart within the tree rows, with $14 \mathrm{~m}$ between rows. The rows of trees were two meters wide, and covered by spontaneous herbaceous vegetation. After tree planting, sunflower (Helianthus annuus L.), wheat (Triticum aestivum L. subsp. aestivum) and barley (Hordeum vulgare L.) were grown in rotation in the control plot and in the inter-rows (Table 2). Crop residues were left in the field after harvest. The soil was ploughed every three years to a depth of $10-20 \mathrm{~cm}$ in both the agroforestry inter-rows and the control plot.

The VE silvoarable site was located in Vézénobres (Fig. 1), in the department of Gard (longitude $4^{\circ} 06^{\prime} 37^{\prime}$ ' E, latitude $46^{\circ} 00^{\prime} 39^{\prime \prime} \mathrm{N}$, elevation $102 \mathrm{~m}$ a.s.l.). The climate was subhumid Mediterranean with a mean temperature of $14.5^{\circ} \mathrm{C}$ and a mean annual rainfall of 1037 mm (mean 1995-2007, experimental site weather station). The soil was a deep sandy loam alluvial Fluvisol (IUSS Working Group WRB, 2007) (Table 1) originating from deposits from the granitic Cevennes mountain range and was, therefore, not calcareous. Hybrid walnut trees 
(Juglans regia $\times$ nigra cv. NG23) were planted in 1995 at a density of 100 trees ha ${ }^{-1}$. The trees were planted $10 \mathrm{~m}$ apart with the rows, with $10 \mathrm{~m}$ between rows. The tree rows were two meters wide and were covered by spontaneous herbaceous vegetation. In the inter-rows, rapeseed (Brassica napus L.) and wheat (Triticum aestivum L. subsp. aestivum) were grown in rotation until 2010 (Table 2). In 2011, the farm changed over to organic farming and potatoes were planted (Solanum tuberosum L.). In 2012 garlic (Allium sativum L.) was grown in the interrows. In 2013 the inter-rows were left fallow and in 2014 sunflower (Helianthus annuus L.) was sown. The same crops were grown in the control plot, except in 2011 when wheat (Triticum aestivum L. subsp. aestivum) was sown and in 2012 when the control was left fallow. The soil was occasionally ploughed to a depth of $20 \mathrm{~cm}$ in both the agroforestry inter-rows and the control plot.

The RE site was located in Prades-le-Lez, at the Restinclières experimental site (Fig. 1), in the department of Hérault (longitude $04^{\circ} 01^{\prime}$ E, latitude $43^{\circ} 43^{\prime} \mathrm{N}$, elevation $54 \mathrm{~m}$ a.s.l.). A full description of this site is given in the study by Cardinael et al. (2015b). The climate was subhumid Mediterranean with a mean temperature of $15.4^{\circ} \mathrm{C}$ and a mean annual rainfall of 873 mm (years 1995-2013, experimental site weather station). The soil was a deep carbonated sandy loam Fluvisol (IUSS Working Group WRB, 2007) (Table 1). Hybrid walnut trees (Juglans regia $\times$ nigra cv. NG23) were planted in 1995 and the density was 110 trees ha $^{-1}$ at the time of the study (Table 2). The trees were planted 4 to $8 \mathrm{~m}$ apart along the rows with $13 \mathrm{~m}$ between rows. The two meter wide tree rows were covered by spontaneous herbaceous vegetation. They were mainly intercropped with durum wheat (Triticum turgidum L. subsp. durum) but also with rapeseed (Brassica napus L.) and chickpea (Cicer arietinum L.). The soil was regularly ploughed to a depth of $20 \mathrm{~cm}$ in both the agroforestry inter-rows and the control plot. 
The TH silvopastoral site was located at the Theix experimental site (Fig. 1), in the department of Puy-de-Dôme (longitude $3^{\circ} 01^{\prime} 39^{\prime}$ ' E, latitude 4542'58' $\mathrm{N}$, elevation $829 \mathrm{~m}$ a.s.l.). The mean temperature was $7.7^{\circ} \mathrm{C}$ and the mean annual rainfall $800 \mathrm{~mm}$ (years 1990-2013, INRA CLIMATIK, https://intranet.inra.fr/climatik). The soil was a clay loam Andosol (IUSS Working Group WRB, 2007) (Table 1). Wild cherry trees (Prunus avium L.) were planted in 1988 at a density of 200 trees $\mathrm{ha}^{-1}$ on a natural permanent pasture. The trees were planted $7 \mathrm{~m}$ apart and the soil was uniformly covered by a permanent pasture, mainly ryegrass (Lolium perenne L.) and fescue (Festuca sp.), in both the control and agroforestry plots (Table 2). There was no distinction between tree rows and inter-rows in terms of soil cover and management. The pasture was regularly grazed by sheep in both the control and agroforestry plots.

\subsection{Soil sampling protocol}

The sampling protocol was defined to allow for the spatial distribution of SOC stocks owing to the presence of trees and rows of trees, with sampling points at varying distances from the trees. The agroforestry designs varied between sites with different distances between the trees within the rows and between the rows. The sampling protocol was flexible to take account of these differences but consistent enough to allow comparisons between sites. A sampling pattern was defined with sampling points in transects around one tree. This was a rectangle with dimensions $\frac{L}{2} \times \frac{d}{2}$, where $L$ is the distance between tree rows and $d$ is the distance between trees in the rows (Fig. 2). This pattern is a quarter of the Voronoi polygon which is the elementary space defined by the half distances between the sampled tree and its neighbors, as commonly used to estimate root biomass (Levillain et al., 2011; Picard et al., 2012). At all sites, nine soil samples per pattern were taken at fixed positions around the trees, at 1,2 and $3 \mathrm{~m}$ in the tree row, in the inter-row in front of the tree, and in the inter-row between two trees. If $\mathrm{L} \geq 8 \mathrm{~m}$, soil samples 
213 were additionally taken at mid-distance $\frac{L}{2}$, and, if $L \geq 16 \mathrm{~m}$, soil samples were also taken at $\frac{L}{4}$. If $214 \mathrm{~d} \geq 8 \mathrm{~m}$, soil samples were also taken at $\frac{d}{2}$. This sampling pattern was applied three times in the 215 agroforestry plots at all sites. Two sampling patterns were oriented north of the tree rows (if the rows were oriented east-west) or west of the rows (if the rows were oriented north-south) and one sampling pattern was oriented south or east, respectively. Thirty-six sampling points were, therefore, defined for the agroforestry plot at the $\mathrm{CH}$ site, twenty-four at the $\mathrm{SJ}$ site, thirty at the VE site, and twenty-seven at the TH site (Table 3). In the control plots, a simpler sampling pattern was applied in triplicate. This pattern was a rectangle with dimensions $\frac{L}{2} \times \frac{d}{2}$, with soil samples taken at each corner (12 sampling points).

At the ME site, the agricultural control plot was flat, whereas the agroforestry plot was on a moderate slope. The SOC-rich topsoil in the agroforestry plot might, therefore, have been eroded before the start of the experiment. To take account of this topography difference, six wide and the 6-year-old trees were only $3 \mathrm{~m}$ high, the soil in the middle of the inter-rows had probably not yet been affected by the presence of trees. 30 sampling points were defined in the agroforestry plot and 6 in the control plot (Table 3).

The RE site had been the subject of a previous study (Cardinael et al., 2015b) to map SOC stocks at plot scale. The sampling protocol at this site was, therefore, very dense: 100 soil samples were taken from the agroforestry plot and 93 from the control plot (Table 3). Sampling points were located every $5 \mathrm{~m}$ along a regular grid $(25 \times 25 \mathrm{~m})$, and at 1,2 and $3 \mathrm{~m}$ around nine walnut trees, in the inter-rows and in the tree rows.

The sampling depths were $30 \mathrm{~cm}$ at the $\mathrm{CH}$ and $\mathrm{ME}$ sites, $20 \mathrm{~cm}$ at the $\mathrm{SJ}$ site, 60 at the VE site, 100 at the RE site and $50 \mathrm{~cm}$ at the TH site. At the SJ site, the sampling depth corresponded 

at the RE site (at $10 \mathrm{~cm}$ and every $20 \mathrm{~cm}$ from $10 \mathrm{~cm}$ ).

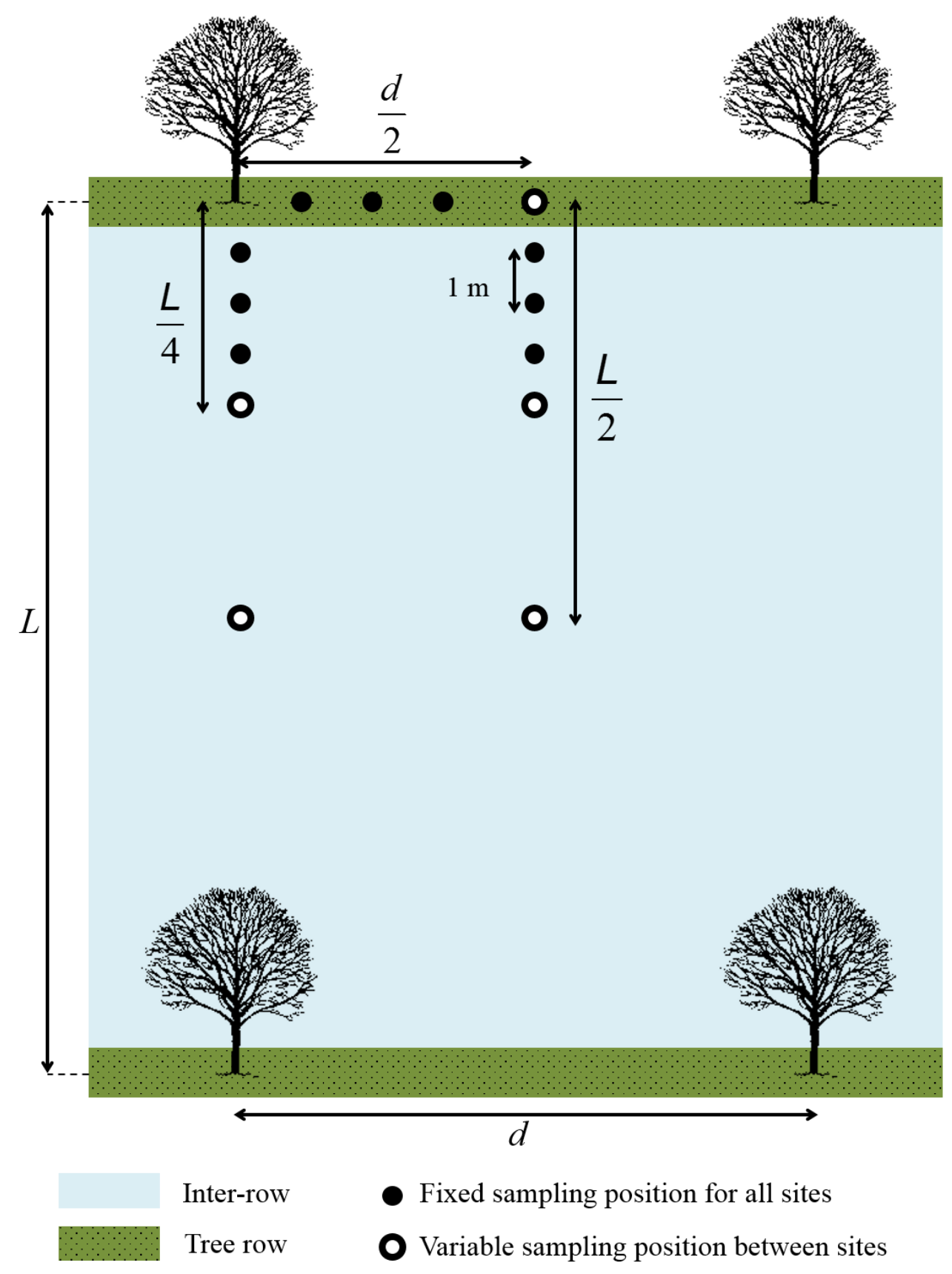

Figure 2. Sampling pattern for the agroforestry sites (except for the RE site). $L$ is the distance between tree rows, $d$ is the distance between trees on the rows. 
244

245

The soil samples were collected in April 2014 at all sites, except at the RE site which was sampled in May 2013. Soil samples were taken every $10 \mathrm{~cm}$ from the surface using a $500-\mathrm{cm}^{3}$ cylinder, except at the RE site where soil samples were taken every $20 \mathrm{~cm}$ depth after the top $10 \mathrm{~cm}$. After air-drying in the lab, the soil samples were oven-dried at $105^{\circ} \mathrm{C}$ for 48 hours, sieved to $2 \mathrm{~mm}$ and weighed without coarse particles $>2 \mathrm{~mm}$. The bulk density $\left(\mathrm{g} \mathrm{cm}^{-3}\right)$ was calculated as the ratio of the dry mass of fine soil $(<2 \mathrm{~mm})$ to the cylinder volume.

\subsection{Organic carbon analysis}

The soil samples were dried at $40^{\circ} \mathrm{C}$ and ball milled until they passed through a $200 \mu \mathrm{m}$ mesh sieve. The presence of inorganic carbon was tested with $\mathrm{HCl}$. If the soil contained inorganic carbon, carbonates were removed by acid fumigation, as described in Harris et al. (2001). This was the case for samples from the SJ and RE sites. $30 \mathrm{mg}$ of soil were placed in open Ag-foil capsules. The capsules were then placed in the wells of a microtiter plate and $50 \mu \mathrm{L}$ of demineralized water was added to each capsule. The microtiter plate was placed in a vacuum desiccator with a beaker filled with $100 \mathrm{~mL}$ of concentrated $\mathrm{HCl}$. The samples were exposed to $\mathrm{HCl}$ vapor for $8 \mathrm{~h}$ and then dried at $40^{\circ} \mathrm{C}$ for $48 \mathrm{~h}$. The capsules were then enclosed in a bigger tin capsule. All samples were analyzed for organic carbon concentration using a CHN elemental analyzer (Carlo Erba NA 2000, Milan, Italy).

\subsection{SOC stock calculation}

The SOC stock at soil sample level $\left(\mathrm{mg} \mathrm{C} \mathrm{cm}^{-3}\right)$ is defined as the product of the SOC concentration $\left(\mathrm{mg} \mathrm{C} \mathrm{g}^{-1}\right)$ and the bulk density $\left(\mathrm{g} \mathrm{cm}^{-3}\right)$ and is then calculated for each soil profile 
$\left(\mathrm{kg} \mathrm{C} \mathrm{m}^{-2}\right)$ by summing the SOC stocks in the samples through the profile. For each site, the SOC stocks were calculated on an equivalent soil mass (ESM) basis (Ellert and Bettany, 1995) to enable comparison between all locations (control, tree rows, inter-rows) even where the soil bulk density varied within the same site. SOC stocks in the agroforestry plot $\left(\mathrm{Mg} \mathrm{C} \mathrm{ha}^{-1}\right)$ were calculated by adding the tree row and inter-row SOC stocks, weighted by their respective relative surface areas:

SOC stock Agroforestry $_{\text {An }}=\frac{p \times \text { SOC stock }_{\text {Tree row }}+(100-p) \times \text { SOC stock }_{\text {Inter-row }}}{100}$

where $p$ is the percentage of tree row surface area in the agroforestry plot (Table 2).

The delta SOC stock $\left(\mathrm{Mg} \mathrm{C} \mathrm{ha}^{-1}\right)$ at a given depth was expressed as the difference in the SOC stock between the agroforestry and the control plot:

$$
\Delta_{\text {SOC stock }}=\text { SOC stock } \text { Agroforestry }- \text { SOC stock } \text { Control }
$$

The SOC stock accumulation rates under an agroforestry system at a given depth was calculated by dividing the delta SOC stock by the number of years since tree planting.

\subsection{Tree aboveground and belowground biomass}

At each site, 10 to 20 trees were measured to estimate the aboveground biomass. As the trees in the farmers' fields could not be felled, the aboveground biomass was estimated by multiplying the volume of the trunk and branches by the wood density, using the global wood density database (Chave et al., 2009). The trunk volume was estimated as the sum of the volume of three truncated cones, from the soil surface up to $1.30 \mathrm{~m}$, from $1.30 \mathrm{~m}$ to the first branch and 
from the first branch to the top of the tree. The trunk diameter was measured $5 \mathrm{~cm}$ above the soil surface, at $1.30 \mathrm{~m}$ (Diameter at Breast Height, DBH) and below the first branch. The total height $\left(\mathrm{H}_{\text {tot }}\right)$ and merchantable height $(\mathrm{H})$ of the trees were also measured. The volume of the first order branches (branches arising directly off the trunk) was also estimated by measuring the diameter of the branches at the trunk and the length of the branches and branch volumes were calculated as cone volumes. For the RE site, three trees were felled to measure the trunk and branch biomass directly. The carbon concentrations of the trunk and branches of the Juglans regia $\times$ nigra $\mathrm{cv}$. NG23 were measured. As it was not possible to sample wood from the tree trunks at the other sites, the $\mathrm{C}$ concentrations were considered to be the same for Prunus avium and Juglans nigra. This simplification was possible because these trees are slow growing species and there is usually little variation in their wood C concentration (462.7 to $499.7 \mathrm{mg} \mathrm{C}$ $\mathrm{g}^{-1} \mathrm{DM}$ ) (Lamlom and Savidge, 2003). It was also assumed that young and old trees had the same wood density and C concentration.

So far as we are aware, there is no allometric equation for estimating the belowground biomass of temperate agroforestry trees and so the equation proposed by Cairns et al. (1997) for temperate forests was used:

$$
\mathrm{RB}=e^{-1.3267+0.8877 \times \ln (A B)+0.1045 \times \ln (\text { Age })}
$$

where $\mathrm{RB}$ is the total root biomass $\left(\mathrm{Mg} \mathrm{C} \mathrm{ha}^{-1}\right), \mathrm{AB}$ is the aboveground biomass $(\mathrm{Mg} \mathrm{C} \mathrm{ha-1)}$ and Age is the age of the plantation (yr).

\subsection{Statistical analyses}

The influence of the sampling location in the inter-rows (in front of a tree or between two trees) on the SOC concentration, bulk density and SOC stock was determined using mixed effects 
models. This analysis was done at each site using the nlme package (Pinheiro et al., 2013). An ANOVA was performed on these models. Mixed effects models were then fitted for each site using the whole soil data set. The SOC concentration, bulk density and SOC stock were compared as a function of depth, location (control, tree row, inter-row) and distance from the closest tree. An ANOVA was performed on these models. The SOC stock were compared between tree rows and inter-rows, between inter-rows and the control plot and between the agroforestry plot and the control plot. The statistical analyses were performed using $\mathrm{R}$ version 3.1.1 (R Development Core Team, 2013), at a significance level of $<0.05$.

\section{Results}

\subsection{Soil bulk density}

At all sites, the soil bulk density increased significantly with increasing soil depth (Table 3, S1). In the top $30 \mathrm{~cm}$, the bulk density ranged from 0.7 to $1.6 \mathrm{~g} \mathrm{~cm}^{-3}$ depending on the site. There was no significant difference in bulk density between the tree row and the inter-row except in the top $10 \mathrm{~cm}$ at the ME, SJ and RE sites, where it was lower in the tree row than in the interrow and in the control (Table 3, S1). There was no significant difference between the control and the inter-row at any depth, except at the RE site where the bulk density was higher in the top $10 \mathrm{~cm}$ in the control plot (Table 3, S1).. The distance from the closest tree had no significant effect on the bulk density except at the SJ site (Table S1). There was no significant difference in the inter-row between samples collected in front of a tree or between two trees at any of the sites or at any depth ( $p$-value $\geq 0.18)$, except at the ME site ( $p$-value $=0.03)($ Table S1). 
Table 3 Mean soil bulk density $\left(\mathrm{g} \mathrm{cm}^{-3}\right)$ and mean soil organic carbon (SOC) concentrations $\left(\mathrm{mg} \mathrm{C} \mathrm{g}^{-1}\right)$ with associated standard errors.

\begin{tabular}{|c|c|c|c|c|c|c|c|c|c|c|}
\hline \multirow[b]{2}{*}{ Site } & \multirow[b]{2}{*}{ Soil depth $(\mathrm{cm})$} & \multicolumn{3}{|c|}{ Number of soil samples } & \multicolumn{3}{|c|}{ Bulk density $\left(\mathrm{g} \mathrm{cm}^{-3}\right)$} & \multicolumn{3}{|c|}{ SOC concentration $\left(\mathrm{mg} \mathrm{C} \mathrm{g}^{-1}\right)$} \\
\hline & & Tree row & Inter-row & Control & Tree row & Inter-row & Control & Tree row & Inter-row & Control \\
\hline \multirow{3}{*}{$\mathrm{CH}$} & $0-10$ & 12 & 24 & 12 & $1.09 \pm 0.03$ & $1.10 \pm 0.02$ & $1.18 \pm 0.02$ & $19.44 \pm 1.00$ & $16.44 \pm 0.26$ & $14.88 \pm 0.38$ \\
\hline & $10-20$ & 12 & 24 & 12 & $1.12 \pm 0.02$ & $1.13 \pm 0.02$ & $1.16 \pm 0.03$ & $13.58 \pm 0.31$ & $14.39 \pm 0.34$ & $14.56 \pm 0.48$ \\
\hline & $20-30$ & 12 & 24 & 12 & $1.15 \pm 0.02$ & $1.20 \pm 0.01$ & $1.25 \pm 0.02$ & $11.76 \pm 0.65$ & $12.07 \pm 0.48$ & $11.78 \pm 0.35$ \\
\hline \multirow{3}{*}{ ME } & $0-10$ & 12 & 18 & 6 & $1.04 \pm 0.03$ & $1.27 \pm 0.02$ & $1.31 \pm 0.01$ & $21.30 \pm 0.63$ & $13.01 \pm 0.19$ & $12.80 \pm 0.43$ \\
\hline & $10-20$ & 12 & 18 & 6 & $1.28 \pm 0.02$ & $1.29 \pm 0.02$ & $1.37 \pm 0.03$ & $13.14 \pm 0.26$ & $12.03 \pm 0.50$ & $12.02 \pm 0.40$ \\
\hline & $20-30$ & 12 & 18 & 6 & $1.21 \pm 0.01$ & $1.34 \pm 0.01$ & $1.35 \pm 0.02$ & $10.35 \pm 0.21$ & $8.38 \pm 0.44$ & $8.68 \pm 0.93$ \\
\hline \multirow{2}{*}{ SJ } & $0-10$ & 8 & 16 & 12 & $0.67 \pm 0.03$ & $0.76 \pm 0.02$ & $0.78 \pm 0.01$ & $58.60 \pm 1.88$ & $49.49 \pm 1.28$ & $32.89 \pm 0.33$ \\
\hline & $10-20$ & 8 & 16 & 12 & $0.84 \pm 0.03$ & $0.78 \pm 0.03$ & $0.88 \pm 0.04$ & $35.60 \pm 0.82$ & $32.01 \pm 0.67$ & $24.86 \pm 1.12$ \\
\hline \multirow{6}{*}{ VE } & $0-10$ & 12 & 18 & 10 & $1.06 \pm 0.04$ & $0.98 \pm 0.03$ & $0.91 \pm 0.02$ & $17.25 \pm 0.49$ & $15.95 \pm 0.37$ & $15.00 \pm 1.11$ \\
\hline & $10-20$ & 12 & 18 & 10 & $1.12 \pm 0.02$ & $1.18 \pm 0.02$ & $1.24 \pm 0.03$ & $13.72 \pm 0.40$ & $13.50 \pm 0.49$ & $13.19 \pm 0.70$ \\
\hline & $20-30$ & 12 & 18 & 10 & $1.16 \pm 0.03$ & $1.25 \pm 0.01$ & $1.31 \pm 0.02$ & $11.38 \pm 0.30$ & $10.83 \pm 0.25$ & $10.89 \pm 0.68$ \\
\hline & $30-40$ & 12 & 18 & 10 & $1.29 \pm 0.04$ & $1.39 \pm 0.02$ & $1.47 \pm 0.04$ & $10.82 \pm 0.27$ & $10.31 \pm 0.29$ & $8.55 \pm 0.78$ \\
\hline & $40-50$ & 12 & 18 & 10 & $1.30 \pm 0.05$ & $1.37 \pm 0.03$ & $1.34 \pm 0.03$ & $10.52 \pm 0.33$ & $8.25 \pm 0.35$ & $5.79 \pm 0.69$ \\
\hline & $50-60$ & 12 & 18 & 10 & $1.36 \pm 0.04$ & $1.39 \pm 0.04$ & $1.37 \pm 0.06$ & $9.74 \pm 0.35$ & $7.16 \pm 0.62$ & $5.28 \pm 0.86$ \\
\hline \multirow{5}{*}{ RE } & $0-10$ & 40 & 60 & 93 & $1.10 \pm 0.02$ & $1.23 \pm 0.03$ & $1.41 \pm 0.01$ & $21.59 \pm 0.76$ & $9.78 \pm 0.13$ & $9.33 \pm 0.06$ \\
\hline & $10-30$ & 40 & 60 & 93 & $1.49 \pm 0.01$ & $1.60 \pm 0.02$ & $1.61 \pm 0.00$ & $10.16 \pm 0.16$ & $9.57 \pm 0.12$ & $8.94 \pm 0.05$ \\
\hline & $30-50$ & 40 & 60 & 93 & $1.71 \pm 0.01$ & $1.67 \pm 0.02$ & $1.73 \pm 0.00$ & $7.29 \pm 0.15$ & $6.95 \pm 0.11$ & $6.82 \pm 0.10$ \\
\hline & $50-70$ & 40 & 60 & 93 & $1.73 \pm 0.01$ & $1.77 \pm 0.01$ & $1.80 \pm 0.00$ & $6.07 \pm 0.11$ & $5.89 \pm 0.07$ & $5.77 \pm 0.06$ \\
\hline & $70-100$ & 40 & 60 & 93 & $1.68 \pm 0.00$ & $1.71 \pm 0.00$ & $1.74 \pm 0.00$ & $6.49 \pm 0.16$ & $6.29 \pm 0.06$ & $6.09 \pm 0.06$ \\
\hline \multirow{5}{*}{$\mathrm{TH}$} & $0-10$ & \multicolumn{2}{|c|}{27} & 10 & \multicolumn{2}{|c|}{$0.75 \pm 0.02$} & $0.69 \pm 0.02$ & \multicolumn{2}{|c|}{$64.00 \pm 2.40$} & $67.83 \pm 2.45$ \\
\hline & $10-20$ & \multicolumn{2}{|c|}{27} & 10 & \multicolumn{2}{|c|}{$0.79 \pm 0.01$} & $0.75 \pm 0.01$ & \multicolumn{2}{|c|}{$46.97 \pm 1.15$} & $49.31 \pm 0.89$ \\
\hline & $20-30$ & \multicolumn{2}{|c|}{27} & 10 & \multicolumn{2}{|c|}{$0.80 \pm 0.02$} & $0.73 \pm 0.02$ & \multicolumn{2}{|c|}{$38.82 \pm 0.88$} & $40.56 \pm 0.86$ \\
\hline & $30-40$ & \multicolumn{2}{|c|}{27} & 10 & \multirow{2}{*}{\multicolumn{2}{|c|}{$0.82 \pm 0.01$}} & $0.78 \pm 0.02$ & \multicolumn{2}{|c|}{$32.90 \pm 0.70$} & $29.92 \pm 0.75$ \\
\hline & $40-50$ & \multicolumn{2}{|c|}{19} & 10 & & & $0.79 \pm 0.03$ & \multicolumn{2}{|c|}{$28.65 \pm 0.76$} & $22.69 \pm 1.25$ \\
\hline
\end{tabular}


CH: Châteaudun, ME: Melle, SJ: Saint-Jean-d'Angély, VE: Vézénobres, RE: Restinclières, TH: Theix. 

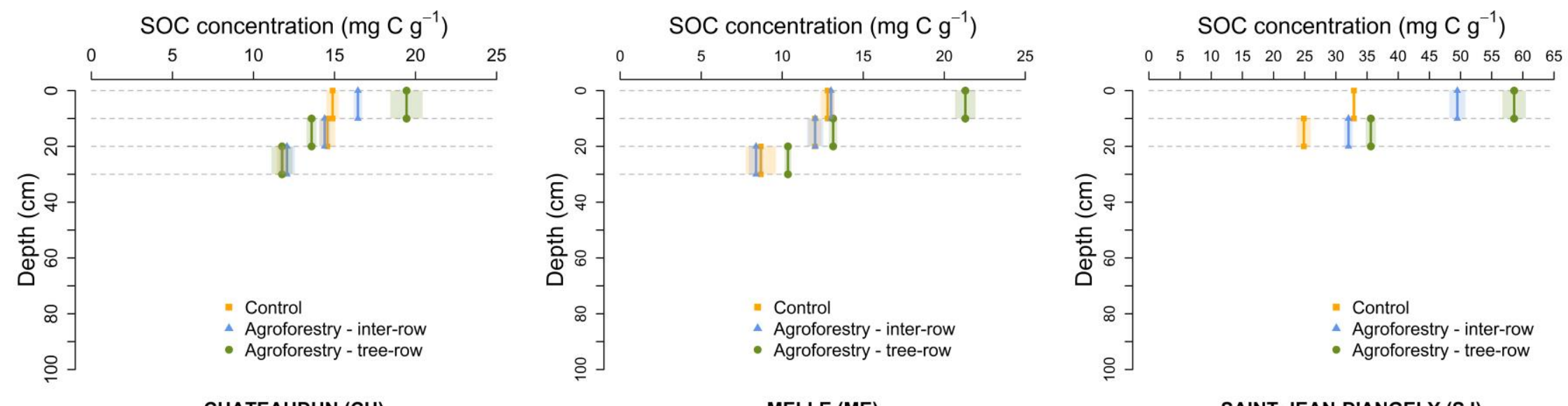

\section{CHATEAUDUN (CH)}
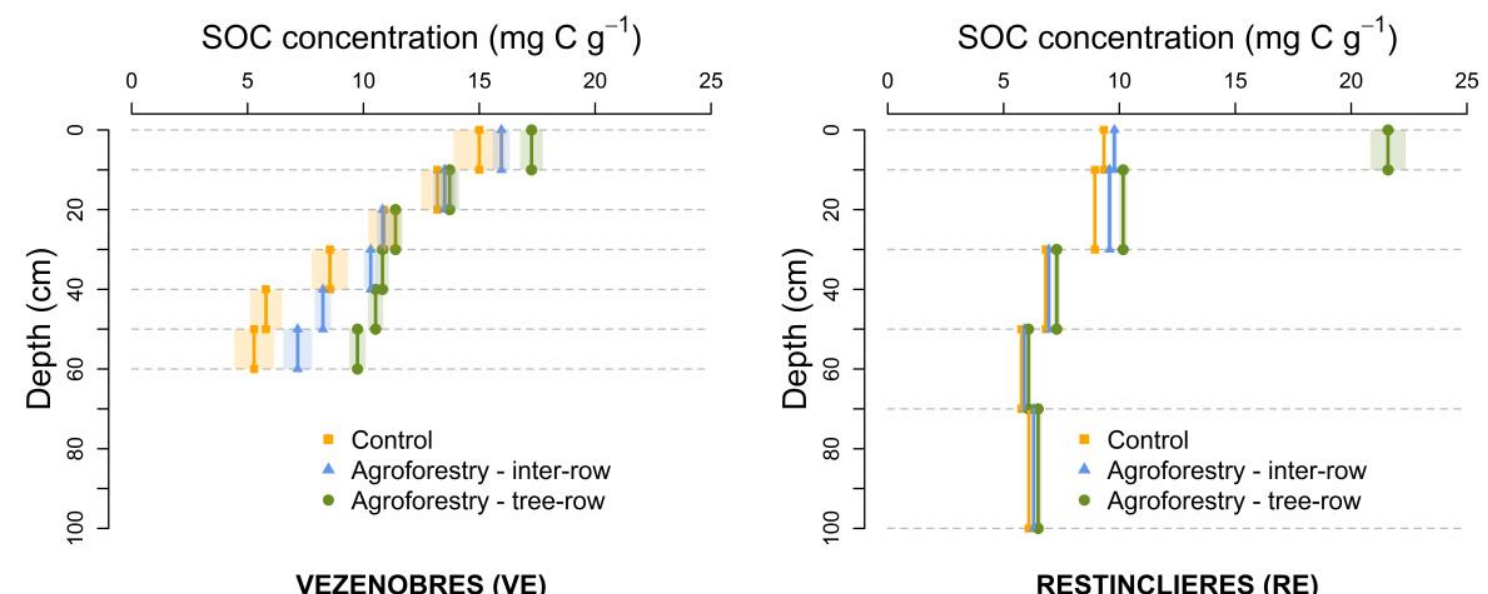

SAINT-JEAN-D'ANGELY (SJ)

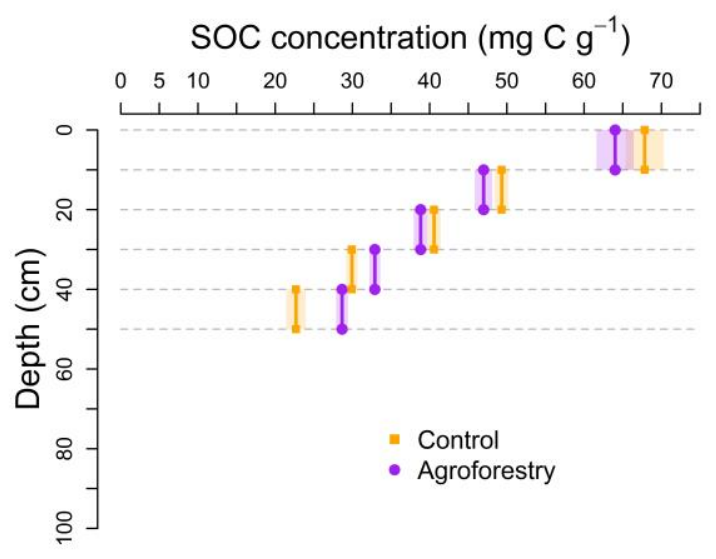

THEIX (TH)

Figure 3. Soil organic carbon concentration $\left(\mathrm{mg} \mathrm{C} \mathrm{g}^{-1}\right)$ at the different sites. Transparent rectangles represent standard errors. At the TH silvopastoral site, no distinction was made between tree rows and inter-rows (uniform cover), values are for the whole agroforestry plot. 
The SOC concentration decreased significantly with increasing soil depth, except in the ploughed layer, where it was uniform (Table 3, S1). At all sites, the SOC concentration in the top $10 \mathrm{~cm}$ was significantly higher in the tree row than in the inter-row (Fig. 3). However, there was no significant difference in the inter-row between samples collected in front of a tree and between two trees ( $p$-value $\geq 0.32$ ) at any site and at any depth. The SOC concentration depended significantly on the distance from the trees only at the oldest site (SJ, p-value $<0.001)$ (Table S1). At sites $\mathrm{CH}, \mathrm{SJ}$ and RE, the SOC concentration in the top $10 \mathrm{~cm}$ was significantly higher in the inter-rows than in the control plot (Fig. 3, Table 3). At the VE and RE silvoarable sites, the SOC concentration was significantly higher in the inter-row than in the control below $30 \mathrm{~cm}$ (Fig. 3, Table 3). At the TH silvopastoral site, the SOC concentration below $30 \mathrm{~cm}$ was also significantly higher in the silvopasture than in the tree-less pasture (Fig. 3, Table 3).

\subsection{Soil organic carbon stock}

The SOC stock was mainly influenced by depth and location (Table S1). In the inter-row, there was no significant difference between samples collected in front of a tree and between two trees ( $p$-value $\geq 0.30$ ). The distance from the closest tree had no significant effect on the SOC stock $(p$-value $\geq 0.5)$ except at the SJ site (p-value $=0.005)($ Table $\mathrm{S} 1)$. In the silvoarable systems, the SOC stock was significantly higher in the tree rows than in the inter-rows in the top $10 \mathrm{~cm}$, even in young plantations ( $\mathrm{CH}$ and ME sites) (Fig. 4). The SOC stock was also significantly higher in the inter-rows than in the control at depths of $10 \mathrm{~cm}$ at the $\mathrm{CH}$ site, $20 \mathrm{~cm}$ at the SJ site and $30 \mathrm{~cm}$ at the RE site, as happened for SOC concentration (Fig. 4). Unlike, at the VE site, the SOC stock was higher in the inter-rows than in the control below $30 \mathrm{~cm}$ (Fig. 4). At 
the TH silvopastoral site, the SOC stock below $30 \mathrm{~cm}$ was higher in the agroforestry plot than in the control.

In the top $30 \mathrm{~cm}$, the delta SOC stock between silvoarable systems and control plots was significantly positive except at the ME and VE sites (Table 4). For the silvoarable sites, the delta SOC stock ranged from 0.5 to $4.5 \mathrm{Mg} \mathrm{C} \mathrm{ha}^{-1}$ in the top $30 \mathrm{~cm}$ (Table 4), and was about 19 $\mathrm{Mg} \mathrm{C} \mathrm{ha}^{-1}$ in the top $20 \mathrm{~cm}$ for the oldest silvoarable system (SJ). At the RE and VE silvoarable sites, the delta SOC stock was significantly positive below $30 \mathrm{~cm}$ depth. At the TH silvopastoral site, the delta SOC stock was not significantly different in the top $30 \mathrm{~cm}(-0.16 \pm 0.25 \mathrm{Mg} \mathrm{C}$ $\left.\mathrm{ha}^{-1}\right)$ but was significantly positive for the whole soil profile $\left(0.49 \pm 0.27 \mathrm{Mg} \mathrm{C} \mathrm{ha}^{-1}\right)$ down to $60 \mathrm{~cm}$ (Table 4).

\subsection{Carbon stock in the tree biomass}

The wood density of Juglans regia $\times$ nigra cv. NG23 was $0.62 \mathrm{~g} \mathrm{~cm}^{-3}$, that of Juglans nigra was $0.59 \mathrm{~g} \mathrm{~cm}^{-3}$ and that of Prunus avium was $0.54 \mathrm{~g} \mathrm{~cm}^{-3}$. The $\mathrm{C}$ concentrations of the trunk and branches of 18-year-old Juglans regia $\times$ nigra cv. NG23 were $445.71 \pm 1.04$ and $428.64 \pm$ $1.70 \mathrm{mg} \mathrm{C} \mathrm{g}^{-1} \mathrm{DM}$, respectively. At the silvoarable sites, the organic carbon stocks in the aboveground biomass of the trees ranged from 0.02 to $26.64 \mathrm{Mg} \mathrm{C} \mathrm{ha}^{-1}$ depending on the tree density and age (Table 5). The aboveground tree $\mathrm{C}$ stock was the highest at the silvopastoral site, reaching about $37 \mathrm{Mg} \mathrm{C} \mathrm{ha}^{-1}$. The estimated $\mathrm{C}$ stocks in the tree belowground biomass ranged from 0.01 to $6.61 \mathrm{Mg} \mathrm{C} \mathrm{ha}^{-1}$ at the silvoarable sites and was more than $9 \mathrm{Mg} \mathrm{C}^{-1}$ at the TH silvopastoral site (Table 5). 
Table 4 Soil organic carbon stock $\left(\mathrm{MgC} \mathrm{ha}^{-1}\right)$ and SOC stock accumulation rate $\left(\mathrm{Mg} \mathrm{C} \mathrm{ha}^{-1} \mathrm{yr}^{-1}\right)$.

\begin{tabular}{|c|c|c|c|c|c|c|c|c|c|c|}
\hline \multirow{2}{*}{ Site } & \multirow{2}{*}{$\begin{array}{c}\text { Cumulativ } \\
\text { e ESM } \\
\left(\mathrm{Mg} \mathrm{ha}^{-1}\right) \\
\end{array}$} & \multirow{2}{*}{$\begin{array}{l}\text { Approximate } \\
\text { soil depth } \\
(\mathrm{cm})\end{array}$} & \multicolumn{4}{|c|}{ Cumulative SOC stock $\left(\mathrm{Mg} \mathrm{C} \mathrm{ha}^{-1}\right)$} & \multirow{2}{*}{$\begin{array}{c}\begin{array}{c}\Delta_{\text {SOC stock }} \\
\left(\mathrm{Mg} \mathrm{C} \mathrm{ha}^{-1}\right)\end{array} \\
\mathrm{AF}-\text { Control }\end{array}$} & \multicolumn{3}{|c|}{ SOC stock accumulation rate $\left(\mathrm{Mg} \mathrm{C} \mathrm{ha}^{-1} \mathrm{yr}^{-1}\right)$} \\
\hline & & & Tree row & Inter row & $\mathrm{AF}$ & Control & & AF/Control & Tree row/Control & Inter-row/Control \\
\hline \multirow{3}{*}{$\mathrm{CH}$} & 1000 & $0-10$ & $19.4 \pm 1.0$ & $16.4 \pm 0.3$ & $16.7 \pm 0.3$ & $14.9 \pm 0.4$ & $1.8 \pm 0.5^{*}$ & $0.30 \pm 0.08^{*}$ & $0.76 \pm 0.18^{*}$ & $0.26 \pm 0.08^{*}$ \\
\hline & 2100 & $0-20$ & $34.8 \pm 1.2$ & $32.5 \pm 0.5$ & $32.7 \pm 0.5$ & $31.0 \pm 0.9$ & $1.7 \pm 1.0^{*}$ & $0.28 \pm 0.17^{*}$ & $0.63 \pm 0.25^{*}$ & $0.25 \pm 0.17^{*}$ \\
\hline & 3250 & $0-30$ & $48.4 \pm 1.7$ & $46.6 \pm 1.0$ & $46.7 \pm 1.0$ & $45.0 \pm 1.1$ & $1.7 \pm 1.4^{*}$ & $0.29 \pm 0.24^{*}$ & $0.57 \pm 0.33 *$ & $0.27 \pm 0.25^{*}$ \\
\hline \multirow{3}{*}{$\mathrm{ME}$} & 1000 & $0-10$ & $21.2 \pm 0.6$ & $13.0 \pm 0.2$ & $13.6 \pm 0.2$ & $12.2 \pm 0.3$ & $1.4 \pm 0.4^{*}$ & $0.24 \pm 0.07 *$ & $1.50 \pm 0.11^{*}$ & $0.14 \pm 0.07^{*}$ \\
\hline & 2200 & $0-20$ & $37.2 \pm 0.6$ & $27.7 \pm 0.5$ & $28.4 \pm 0.5$ & $26.4 \pm 0.9$ & $2.0 \pm 1.1^{*}$ & $0.33 \pm 0.18 *$ & $1.79 \pm 0.19^{*}$ & $0.22 \pm 0.18 *$ \\
\hline & 3500 & $0-30$ & $51.1 \pm 0.8$ & $39.9 \pm 0.9$ & $40.7 \pm 0.9$ & $40.1 \pm 1.7$ & $0.5 \pm 2.0$ & $0.09 \pm 0.33$ & $1.83 \pm 0.32 *$ & $-0.04 \pm 0.33$ \\
\hline \multirow{2}{*}{ SJ } & 700 & $0-10$ & $40.6 \pm 1.1$ & $34.6 \pm 0.9$ & $35.5 \pm 0.8$ & $23.0 \pm 0.2$ & $12.4 \pm 0.8^{*}$ & $0.30 \pm 0.02 *$ & $0.43 \pm 0.03 *$ & $0.28 \pm 0.02 *$ \\
\hline & 1450 & $0-20$ & $67.7 \pm 1.1$ & $59.8 \pm 1.0$ & $60.9 \pm 0.9$ & $42.1 \pm 0.8$ & $18.8 \pm 1.2^{*}$ & $0.46 \pm 0.03 *$ & $0.62 \pm 0.03 *$ & $0.43 \pm 0.03^{*}$ \\
\hline \multirow{6}{*}{$\mathrm{VE}$} & 900 & $0-10$ & $15.5 \pm 0.5$ & $14.6 \pm 0.4$ & $14.8 \pm 0.3$ & $13.5 \pm 1.0$ & $1.3 \pm 1.0^{*}$ & $0.07 \pm 0.06^{*}$ & $0.11 \pm 0.06^{*}$ & $0.06 \pm 0.06^{*}$ \\
\hline & 2000 & $0-20$ & $31.2 \pm 0.8$ & $29.5 \pm 0.8$ & $29.8 \pm 0.6$ & $27.9 \pm 1.5$ & $1.9 \pm 1.6^{*}$ & $0.11 \pm 0.09^{*}$ & $0.18 \pm 0.09^{*}$ & $0.09 \pm 0.09^{*}$ \\
\hline & 3150 & $0-30$ & $44.7 \pm 1.0$ & $42.4 \pm 0.9$ & $42.8 \pm 0.8$ & $40.8 \pm 2.0$ & $2.0 \pm 2.2$ & $0.11 \pm 0.12$ & $0.21 \pm 0.12 *$ & $0.09 \pm 0.12$ \\
\hline & 4400 & $0-40$ & $58.1 \pm 1.2$ & $55.1 \pm 1.2$ & $55.7 \pm 1.0$ & $51.8 \pm 2.5$ & $3.9 \pm 2.7^{*}$ & $0.22 \pm 0.15^{*}$ & $0.35 \pm 0.16^{*}$ & $0.19 \pm 0.16^{*}$ \\
\hline & 5700 & $0-50$ & $72.0 \pm 1.5$ & $66.8 \pm 1.3$ & $67.7 \pm 1.1$ & $61.2 \pm 3.2$ & $6.5 \pm 3.4^{*}$ & $0.36 \pm 0.19^{*}$ & $0.60 \pm 0.20^{*}$ & $0.31 \pm 0.19^{*}$ \\
\hline & 7050 & $0-60$ & $85.3 \pm 1.9$ & $77.1 \pm 1.6$ & $78.6 \pm 1.4$ & $68.6 \pm 4.1$ & $10.0 \pm 4.3^{*}$ & $0.56 \pm 0.24 *$ & $0.93 \pm 0.25^{*}$ & $0.48 \pm 0.25^{*}$ \\
\hline \multirow{5}{*}{$\mathrm{RE}$} & 1000 & $0-10$ & $21.6 \pm 1.0$ & $9.8 \pm 0.4$ & $11.7 \pm 0.3$ & $9.3 \pm 0.1$ & $2.3 \pm 0.4^{*}$ & $0.13 \pm 0.02 *$ & $0.68 \pm 0.05^{*}$ & $0.02 \pm 0.02 *$ \\
\hline & 4000 & $0-30$ & $52.8 \pm 1.4$ & $37.9 \pm 0.6$ & $40.3 \pm 0.5$ & $35.8 \pm 0.2$ & $4.5 \pm 0.6^{*}$ & $0.25 \pm 0.03^{*}$ & $0.95 \pm 0.08 *$ & $0.12 \pm 0.03^{*}$ \\
\hline & 7300 & $0-50$ & $77.1 \pm 1.5$ & $62.0 \pm 0.7$ & $64.4 \pm 0.6$ & $59.4 \pm 0.2$ & $5.0 \pm 0.6^{*}$ & $0.28 \pm 0.04 *$ & $0.98 \pm 0.08^{*}$ & $0.14 \pm 0.04 *$ \\
\hline & 10700 & $0-70$ & $98.1 \pm 1.5$ & $82.4 \pm 0.7$ & $84.9 \pm 0.6$ & $79.7 \pm 0.3$ & $5.1 \pm 0.7^{*}$ & $0.29 \pm 0.04 *$ & $1.02 \pm 0.08 *$ & $0.15 \pm 0.04^{*}$ \\
\hline & 15700 & $0-100$ & $130.4 \pm 1.5$ & $113.7 \pm 0.7$ & $116.4 \pm 0.7$ & $110.1 \pm 0.3$ & $6.3 \pm 0.7^{*}$ & $0.35 \pm 0.04 *$ & $1.13 \pm 0.09 *$ & $0.20 \pm 0.05^{*}$ \\
\hline \multirow{5}{*}{ TH } & 700 & $0-10$ & - & - & $44.2 \pm 3.4$ & $47.1 \pm 1.6$ & $-2.9 \pm 3.8$ & $-0.11 \pm 0.14$ & - & - \\
\hline & 1450 & $0-20$ & - & - & $80.4 \pm 5.0$ & $84.1 \pm 1.9$ & $-3.7 \pm 5.3$ & $-0.14 \pm 0.20$ & - & - \\
\hline & 2200 & $0-30$ & - & - & $110.2 \pm 6.1$ & $114.3 \pm 2.3$ & $-4.1 \pm 6.5$ & $-0.16 \pm 0.25$ & - & - \\
\hline & 3000 & $0-40$ & - & - & $137.6 \pm 6.5$ & $138.2 \pm 2.3$ & $-0.5 \pm 6.9$ & $-0.02 \pm 0.26$ & - & - \\
\hline & 3800 & $0-50$ & - & - & $169.3 \pm 6.5$ & $156.5 \pm 2.7$ & $12.8 \pm 7.0^{*}$ & $0.49 \pm 0.27 *$ & - & - \\
\hline
\end{tabular}


Associated errors are standard errors. Approximate depths are presented here to give a better understanding of the ESM for a given site but do not correspond to the precise mass of the profile, which may vary between tree rows, inter-rows and the control (Ellert and Bettany, 1995). At the TH silvopastoral site, no distinction was made between tree rows and inter-rows (uniform cover). Significantly different (p-value $<0.05$ ) delta SOC stock $\left(\Delta_{\text {SOC stock }}\right)$ and additional SOC storage rate are followed by *. ESM: Equivalent Soil Mass, AF: Agroforestry. CH: Châteaudun, ME: Melle, SJ: Saint-Jean-d'Angély, VE: Vézénobres, RE: Restinclières, TH: Theix. 


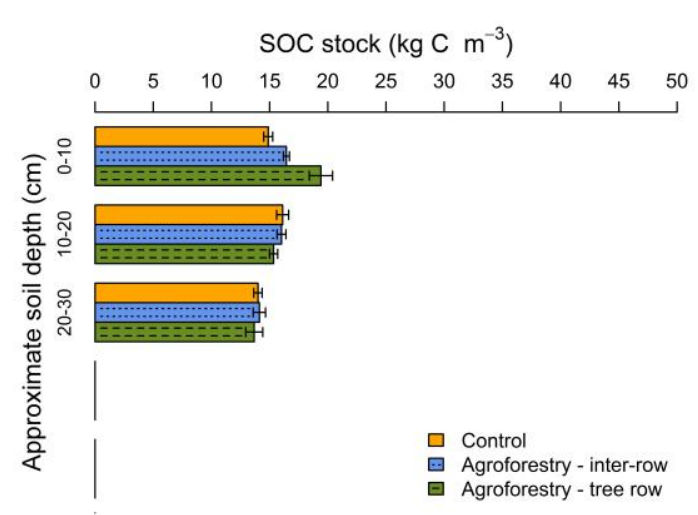

CHATEAUDUN (CH)

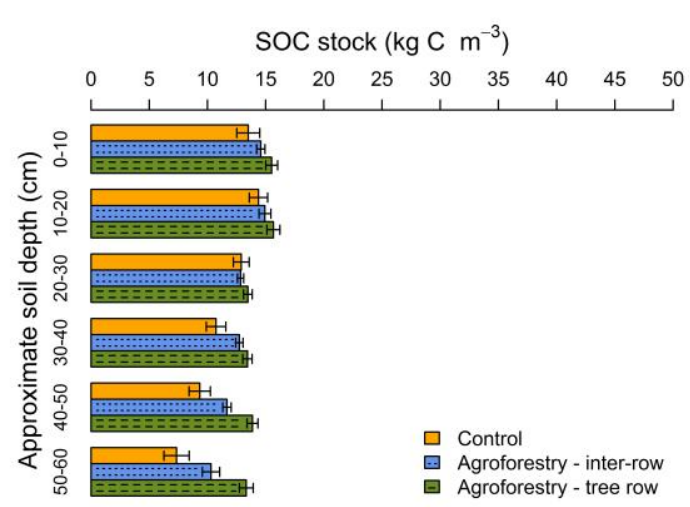

VEZENOBRES (VE)

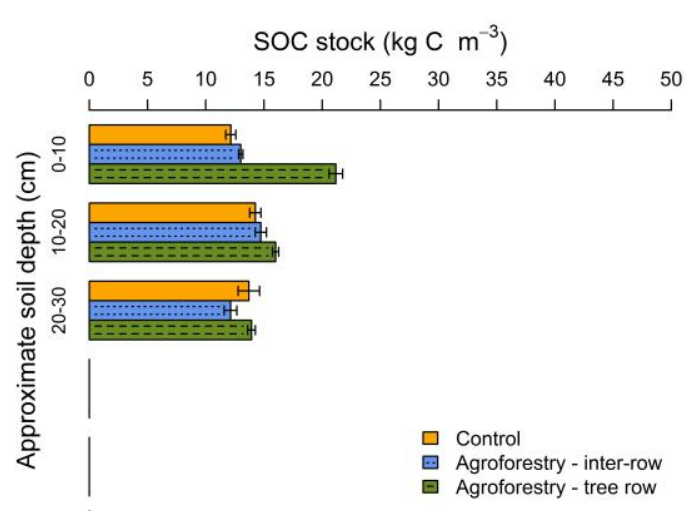

MELLE (ME)

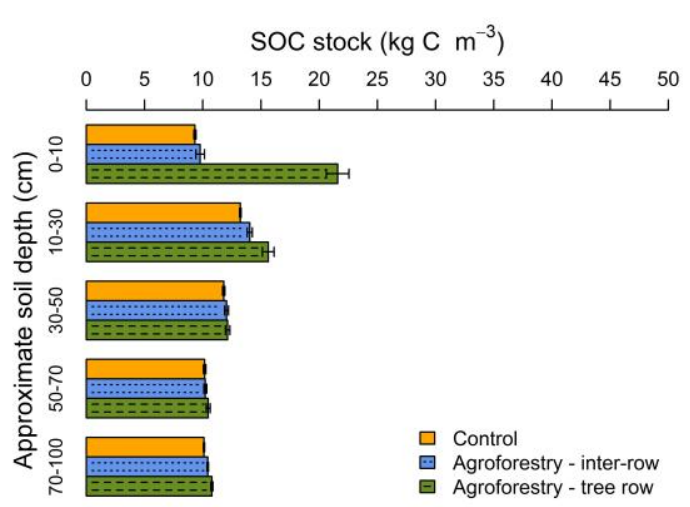

RESTINCLIERES (RE)

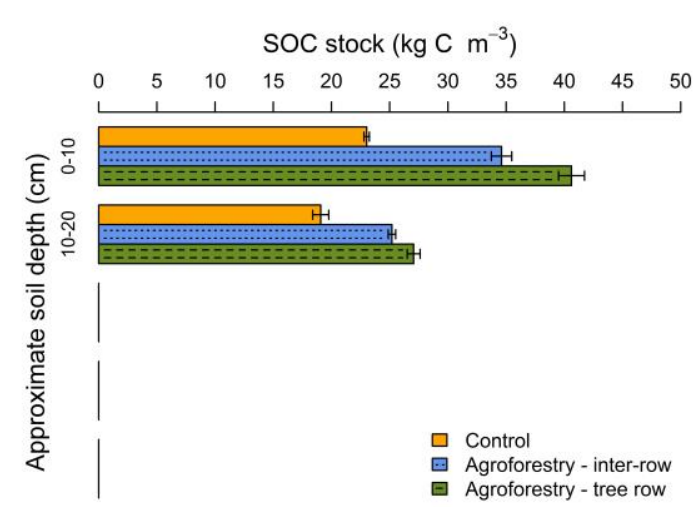

SAINT-JEAN-D'ANGELY (SJ)

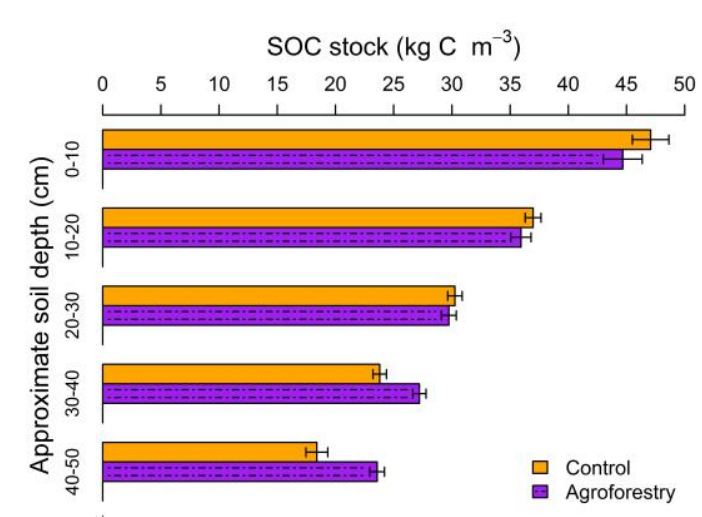

THEIX (TH)

Figure 4. Soil organic carbon stock $\left(\mathrm{kg} \mathrm{C} \mathrm{m}^{-3}\right)$ at the different sites. Bars represent standard errors. Approximate depths are presented but refer to for the whole agroforestry plot. 


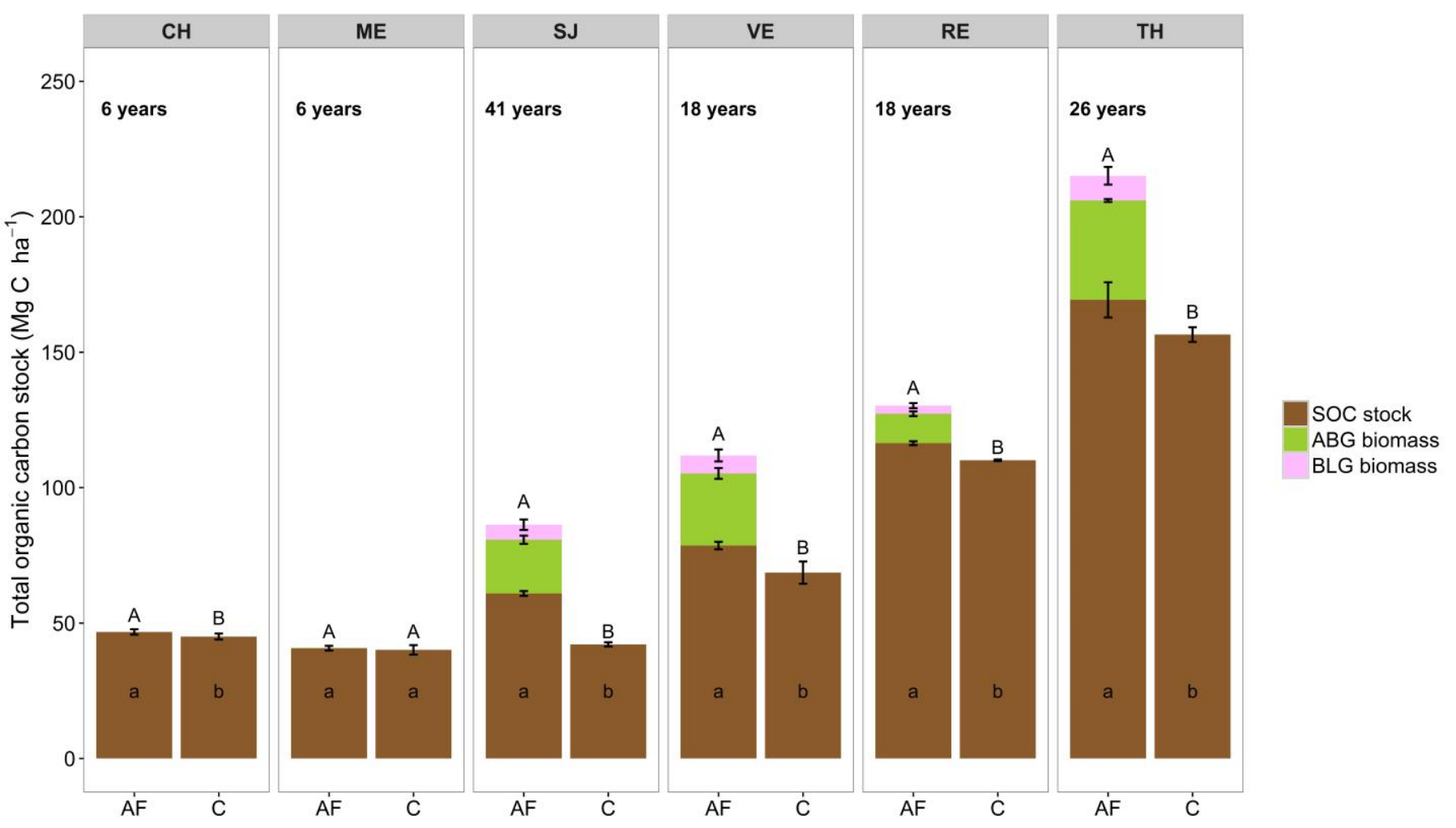

404 Figure 5. Total organic carbon stock $\left(\mathrm{Mg} \mathrm{C} \mathrm{ha}^{-1}\right)$ of the different sites. AF: agroforestry, C: agricultural control. SOC: Soil organic carbon, ABG: Aboveground, BLG: Belowground. CH: Châteaudun, ME: Melle, SJ: Saint-Jean-d’Angély, VE: Vézénobres, RE: Restinclières, TH: Theix. Studied depths vary between sites: $30 \mathrm{~cm}$ for $\mathrm{CH}, 30 \mathrm{~cm}$ for ME, $20 \mathrm{~cm}$ for SJ, $60 \mathrm{~cm}$ for VE, $100 \mathrm{~cm}$ for RE and $50 \mathrm{~cm}$ for TH. Different lowercase letters indicate a significant ( $\mathrm{p}$-value $<0.05$ ) difference of SOC stock between AF and C plots per site, and different uppercase letters indicate a significant difference ( $\mathrm{p}$-value < 0.05$)$ in the total organic carbon stock between AF and C plots per site. 
410

411

412

413

414

415

416

417

418

419

420

421

422

423

424

425

426

427

428

429

430

At the silvoarable sites, the total $\mathrm{C}$ stock ( $\mathrm{SOC}+$ biomass) ranged from about $50 \mathrm{Mg} \mathrm{C}^{-1}$ to

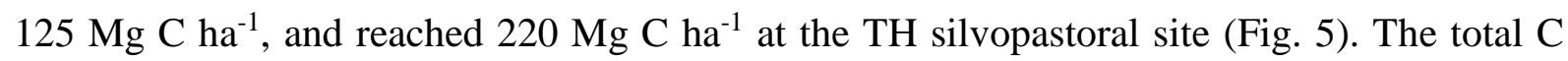
stock was always higher in the agroforestry systems than in the control plots. In the young plantations ( $\mathrm{CH}$ and $\mathrm{ME})$, the total $\mathrm{C}$ stock was mainly $\mathrm{SOC}$, with tree $\mathrm{C}$ stock accounting for less than $0.01 \%$ of the total C stock. At oldest sites, up to $75 \%$ of the difference between total C stock in the agroforestry systems and control plots was explained by the tree biomass (Fig. $5)$.

\subsection{Organic carbon accumulation rate in soil and tree biomass}

The mean SOC stock accumulation rate in the top $30 \mathrm{~cm}$ in the silvoarable systems was 0.18 $\mathrm{MgC} \mathrm{ha}^{-1} \mathrm{yr}^{-1}$ (0.09 to $\left.0.29 \mathrm{MgC} \mathrm{ha}^{-1} \mathrm{yr}^{-1}\right)$. This rate reached $0.24 \mathrm{MgC} \mathrm{ha}^{-1} \mathrm{yr}^{-1}$ when the SJ silvoarable site and its shallow soil $(20 \mathrm{~cm})$ was taken into account. At the RE site, the SOC stock accumulation rate was $0.25 \mathrm{MgC} \mathrm{ha}^{-1} \mathrm{yr}^{-1}$ in the top $30 \mathrm{~cm}$, and $0.35 \mathrm{MgC} \mathrm{ha}^{-1} \mathrm{yr}^{-1}$ in the top $100 \mathrm{~cm}$, with a SOC stock accumulation rate of about $0.1 \mathrm{Mg} \mathrm{C} \mathrm{ha}^{-1} \mathrm{yr}^{-1}$ in the $30-100 \mathrm{~cm}$ layer (Table 4). Tree rows contributed about $20 \%$ to $50 \%$ to the SOC stock accumulation rate although they covered only $7 \%$ to $18 \%$ of the agroforestry surface area.

The $\mathrm{C}$ accumulation rate in the tree biomass in $\mathrm{CH}$ and $\mathrm{ME}$ young plantations was negligible (0.004 and 0.02 $\mathrm{Mg} \mathrm{C} \mathrm{ha}^{-1} \mathrm{yr}^{-1}$, respectively) (Table 5). In the older and denser silvoarable sites, this rate ranged from 0.62 to $1.85 \mathrm{MgC} \mathrm{ha}^{-1} \mathrm{yr}^{-1}$, and was $1.76 \mathrm{Mg} \mathrm{Cha}^{-1} \mathrm{yr}^{-1}$ at the $\mathrm{TH}$ silvopastoral site (Table 5). 
432 Table 5 Tree characteristics, aboveground and belowground carbon stocks at the various sites.

\begin{tabular}{|c|c|c|c|c|c|c|c|c|c|}
\hline Site & $\begin{array}{l}\text { Age } \\
(\mathrm{yr})\end{array}$ & $\mathrm{DBH}(\mathrm{cm})$ & $\begin{array}{l}\text { Height of } \\
\text { merchantable } \\
\text { timber }(\mathrm{m})\end{array}$ & $\begin{array}{l}\text { Total height } \\
\text { (m) }\end{array}$ & $\begin{array}{c}\text { C stock of } \\
\text { merchantable } \\
\text { timber }\left(\mathrm{kg} \mathrm{C} \text { tree }^{-1}\right)\end{array}$ & $\begin{array}{l}\text { ABG tree C } \\
\text { stock } \\
\left(\mathrm{kg} \mathrm{C} \text { tree }^{-1}\right)\end{array}$ & $\begin{array}{l}\text { ABG tree } \mathrm{C} \\
\text { stock } \\
\left(\mathrm{Mg} \mathrm{C} \mathrm{ha-1)}^{-1}\right.\end{array}$ & $\begin{array}{l}\text { Estimated BEG } \\
\text { tree } \mathrm{C} \text { stock } \\
\left(\mathrm{Mg} \mathrm{C} \mathrm{ha-1)}^{-1}\right)\end{array}$ & $\begin{array}{c}\text { Estimated total tree } \mathrm{C} \text { stock } \\
\text { accumulation rate } \\
\left(\mathrm{Mg} \mathrm{C} \mathrm{ha}^{-1} \mathrm{yr}^{-1}\right)\end{array}$ \\
\hline $\mathrm{CH}$ & 6 & $2.6 \pm 0.2$ & $1.45 \pm 0.04$ & $2.12 \pm 0.11$ & $0.44 \pm 0.06$ & $0.49 \pm 0.07$ & $0.017 \pm 0.002$ & $0.01(0.01-0.01)$ & $0.004 \pm 0.0004$ \\
\hline ME & 6 & $5.5 \pm 0.3$ & $1.13 \pm 0.03$ & $3.18 \pm 0.13$ & $1.18 \pm 0.12$ & $2.07 \pm 0.19$ & $0.073 \pm 0.007$ & $0.03(0.03-0.04)$ & $0.02 \pm 0.001$ \\
\hline SJ & 41 & $29.9 \pm 1.3$ & $3.11 \pm 0.23$ & $13.18 \pm 0.10$ & $41.44 \pm 2.36$ & $194.56 \pm 14.94$ & $19.85 \pm 1.52$ & $5.55(3.28-9.38)$ & $0.62 \pm 0.10$ \\
\hline VE & 18 & $31.7 \pm 1.5$ & $4.17 \pm 0.18$ & $15.52 \pm 0.36$ & $56.85 \pm 3.77$ & $266.44 \pm 19.90$ & $26.64 \pm 1.99$ & $6.61(4.00-10.95)$ & $1.85 \pm 0.27$ \\
\hline RE & 18 & $25.5 \pm 1.4$ & $4.49 \pm 0.39$ & $11.21 \pm 0.65$ & $46.23 \pm 2.47$ & $98.93 \pm 7.80$ & $10.88 \pm 0.86$ & $2.99(1.89-4.72)$ & $0.77 \pm 0.11$ \\
\hline TH & 26 & $30.7 \pm 1.4$ & $4.10 \pm 0.23$ & $14.70 \pm 0.32$ & $53.80 \pm 1.76$ & $183.46 \pm 2.66$ & $36.69 \pm 0.53$ & $9.13(5.34-15.63)$ & $1.76 \pm 0.25$ \\
\hline
\end{tabular}

433 Errors represent standard errors. Number of measured trees: $\mathrm{CH}=24, \mathrm{ME}=20, \mathrm{SJ}=10, \mathrm{VE}=10, \mathrm{RE}=9$ except for biomass measurements where $\mathrm{n}=3$,

434 and $\mathrm{TH}=10$. Values in brackets represent the 95\% prediction interval for estimating the belowground biomass (Cairns et al., 1997). ABG:

435 Aboveground, BEG: Belowground. CH: Châteaudun, ME: Melle, SJ: Saint-Jean-d'Angély, VE: Vézénobres, RE: Restinclières, TH: Theix. 


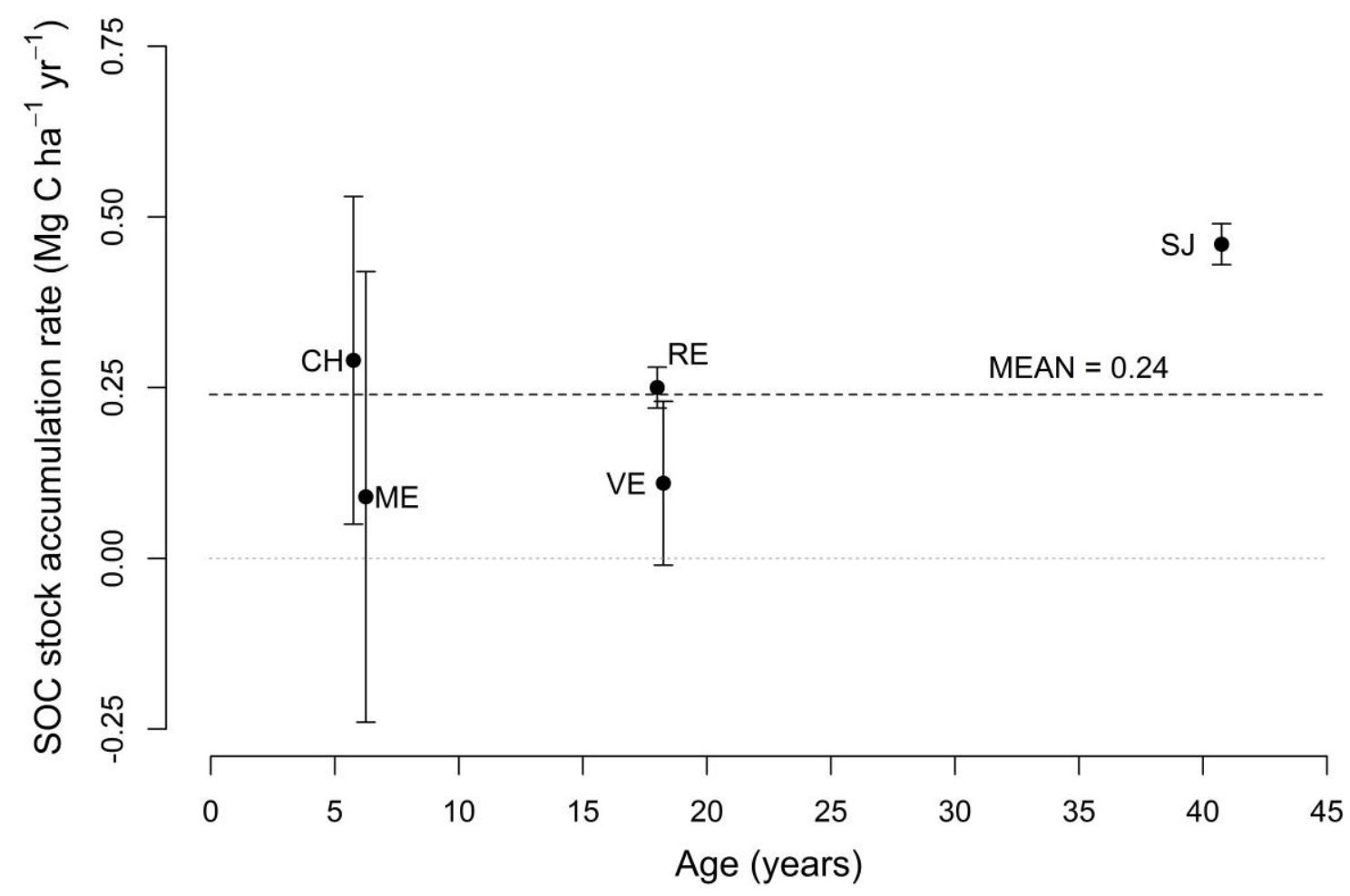

437

438 Figure 6. SOC stock accumulation rates as a function of plantation age. Values are for the 439 approximate top $30 \mathrm{~cm}$, except for the SJ site (approximate top $20 \mathrm{~cm}$, maximum soil 440 depth). 


\section{Discussion}

\subsection{Spatial variation of SOC stock in silvoarable systems}

443 The sampling protocol was designed to take account of the spatial distribution of SOC stocks

444

445 as a function of distance from the trees. Sampling in the inter-rows in front of a tree or between two trees did not affect the estimation of SOC stocks. The protocol could, therefore, be simplified for instance by sampling only in front of a tree or by sampling along the diagonal of the sampling pattern, which was equivalent to a quarter of the Voronoi polygon (Levillain et al., 2011). Field sampling would then be less costly and less time-consuming.

The distance from the trees had no effect on SOC stocks in the inter-rows, except at the oldest SJ site. At this 41-year-old site, the width of the cropped alley had been reduced over the past 10 years owing to light competition, which might explain the gradient of SOC stocks observed. At the RE site, Cardinael et al., (2015b) suggested that close to the trees, organic C input coming from tree fine root senescence (Cardinael et al., 2015a; Germon et al., 2016), exudates and leaves might be compensated by a decrease in organic $\mathrm{C}$ input from crop residues owing to lower yields (Dufour et al., 2013). The same hypothesis might apply at the VE site, where no SOC stock gradient was found in the inter-rows (same tree density, same tree species and tree age as the RE site). Consequently, fewer soil samples could be taken to estimate SOC stock in the inter-rows. However, these two 18-year-old sites had a high tree density, the distance between two tree rows $(11 \mathrm{~m}$ and $13 \mathrm{~m})$ being almost the same as the mean tree height $(15 \mathrm{~m}$ and $11 \mathrm{~m})$. It is possible that a SOC stock gradient may appear with time in the inter-rows in low-density plantations with a large distance between two tree rows $(>30 \mathrm{~m})$. This gradient effect could also depend on the tree species. This hypothesis could be tested in the future at the $\mathrm{CH}$ and ME sites. 
At all the silvoarable sites, the SOC stock was higher in the tree rows than in the inter-rows and in the control plot, especially in the topsoil layer $(0-10 \mathrm{~cm})$. Tree rows therefore had a considerable effect on SOC storage, contributing up to $50 \%$ of the additional SOC storage at silvoarable plot scale for only a small surface area. There were two main sources of organic matter returned to the soil in the tree rows: carbon from the trees (litter, fine roots and exudates) and carbon from the herbaceous vegetation. At the RE site, the aboveground and belowground biomass of the herbaceous vegetation in the tree rows was $2.13 \mathrm{Mg} \mathrm{C} \mathrm{ha}^{-1}$ and $0.74 \mathrm{Mg} \mathrm{C} \mathrm{ha}^{-1}$, respectively (unpublished data). The $\mathrm{C}$ input to the soil from this vegetation in the tree rows could, therefore, be up to $2.9 \mathrm{Mg} \mathrm{C} \mathrm{ha}^{-1} \mathrm{yr}^{-1}$. The spaces between the trees along the tree rows could be considered comparable to grass strips or natural grassland because of the herbaceous cover and the lack of soil tillage. Converting annual crop cultivation to grassland was shown to be very efficient in terms of SOC storage by Conant et al., (2001), Arrouays et al., (2002), and Soussana et al., (2004) with SOC stock accumulation rates ranging from $0.49 \mathrm{Mg} \mathrm{C} \mathrm{ha}^{-1} \mathrm{yr}^{-1}$ to 1.01 $\mathrm{Mg} \mathrm{C} \mathrm{ha}^{-1} \mathrm{yr}^{-1}$ in the top $30 \mathrm{~cm}$. Based on their results and on the high SOC stocks also measured in the topsoil in tree rows of young plantations with small tree biomass, we suggest that a major part of the SOC storage in the tree rows is due to the herbaceous vegetation. There was no clear difference between sown and natural herbaceous vegetation in the tree rows, although the highest SOC stock accumulation rate was obtained for sown grass (ME site, 1.3 $\left.\mathrm{Mg} \mathrm{C} \mathrm{ha}^{-1} \mathrm{yr}^{-1}\right)$. However, the management of these tree rows seems to be a key factor for increasing the SOC storage capacity of silvoarable systems. Several studies showed that including legumes in the composition of grasslands increased herbage productivity (Tilman et al., 2001; Marquard et al., 2009; Prieto et al., 2015) and SOC storage (Steinbeiss et al., 2008; Lange et al., 2015). 
In the five silvoarable systems studied, the mean SOC stock accumulation rate in the top $30 \mathrm{~cm}$ was $0.24(0.09-0.46) \mathrm{Mg} \mathrm{C} \mathrm{ha}^{-1} \mathrm{yr}^{-1}$. This estimate for silvoarable plots with an average age of 17.8 -yr, is slightly lower than previously suggested for 20 -yr-old agroforestry systems in France $\left(0.30(0.03-0.41) \mathrm{Mg} \mathrm{C} \mathrm{ha}^{-1} \mathrm{yr}^{-1}\right)$ by Pellerin et al. (2013) based on a literature review but it is of the same order of magnitude. The SOC stock accumulation rate was also slightly lower than those reported by Oelbermann et al. (2006) for a 13-yr-old Canadian alley cropping system combining hybrid poplars and wheat, soybean and maize grown in rotation $(0.30 \mathrm{Mg} \mathrm{C}$ $\mathrm{ha}^{-1} \mathrm{yr}^{-1}$ in the top $20 \mathrm{~cm}$ and $0.39 \mathrm{Mg} \mathrm{C} \mathrm{ha}^{-1} \mathrm{yr}^{-1}$ in the top $40 \mathrm{~cm}$ ). As well as, Peichl et al. (2006) reported a SOC stock accumulation rate of $1.04 \mathrm{Mg} \mathrm{C} \mathrm{ha}^{-1} \mathrm{yr}^{-1}$ in the top $20 \mathrm{~cm}$ for a 13-yr-old hybrid poplar and Norway spruce-barley agroforestry system. Overall, our estimated SOC stock accumulation rate is slightly lower than most published results (Lorenz and Lal, 2014; Kim et al., 2016). However, as reported by Cardinael et al. (2015b), our study estimated SOC storage in silvoarable systems using the equivalent soil mass, which gives more accurate results when soil bulk density is modified by changes in land use (Ellert and Bettany, 1995; Ellert et al., 2002), as was the case in these systems, especially in the tree rows. Furthermore, most fields in our study were owned and managed by farmers. Although this fact may generate some uncertainties, it has the advantage of taking account of a broad variety of practices that are commonly used by farmers.

At the two 18-year-old silvoarable sites (RE and VE) there was a significant increase in deep SOS stocks (below $30 \mathrm{~cm}$ ). At the VE site this might be partially due to a slightly higher sand content in the control plot than in the agroforestry plot below $30 \mathrm{~cm}$. At the RE site, this increase might result from a high density of deep tree fine roots (Mulia and Dupraz, 2006; Cardinael et al., 2015a). Although the SOC stock accumulation rate was lower than in topsoil layers, deep soil layers might then be able to store a large amount of SOC over a longer period owing to 
better SOC stabilization conditions (Rasse et al., 2005). However, little is known about the effect of fresh organic matter input on deep soil layers and some authors found that this might stimulate the mineralization of old organic matter (Fontaine et al., 2004, 2007).

There was no change in the SOC stock accumulation rates with time in the silvoarable systems (Fig. 6) but very old sites (> 40 year old) were under-represented in this study. It is therefore difficult to assess the possible effect of tree age on the SOC accumulation rate. Tree growth increases organic litter production with time but competition with the intercrop also increases, potentially causing a decrease in crop yields such as cereals (Dufour et al., 2013). In a recent meta-analysis, Kim et al., (2016) found a slight decrease in the SOC stock accumulation rates in very old agroforestry systems, which was attributed to the soil reaching a new SOC stock equilibrium. Based on technical limits (soil depth, water holding capacity, field size), Pellerin et al., (2013) and Chenu et al., (2014) estimated that about $4 \mathrm{M}$ ha of arable land could be converted to silvoarable systems in France. Given the estimated SOC stock accumulation rate in this study, this would mean that $3.610^{5}$ to $1.8410^{6} \mathrm{Mg} \mathrm{C}$ could be stored annually in the soil.

\subsection{Carbon storage in silvopastoral systems}

The silvopastoral system set up on an andosol on permanent grassland (Tables 3 and 4) had no more additional SOC in the top $30 \mathrm{~cm}$ than grassland without trees. This site had been under pasture for decades before tree planting. It had a high SOC concentration (about $65 \mathrm{mg} \mathrm{C} \mathrm{g}^{-1}$ at $0-10 \mathrm{~cm}$ ) and the soil was possibly at a steady state so that it could not store additional SOC, at least in fine soil fractions (Hassink, 1997). On a Patagonian andosol, Dube et al., (2012) also found that there was no significant difference in the SOC stocks in the top $40 \mathrm{~cm}$ of a silvopastoral system compared to a natural pasture. At our site, there was a significant effect of the silvopastoral system on SOC concentration and stock in the 30-50 cm layer: the SOC 
concentration in the silvopastoral system was about $29 \mathrm{mg} \mathrm{C} \mathrm{g}^{-1}$ while in the grassland control it was only about $23 \mathrm{mg} \mathrm{C} \mathrm{g}^{-1}$. It is possible that these deep soil layers in grasslands might be less SOC-saturated than topsoil layers and that roots from agroforestry trees could, therefore, contribute to additional SOC storage at depth. Haile et al. (2010) also found that trees affected deep SOC storage in silvopastoral systems. The biomass production of pastures in silvopastoral systems is usually less sensitive to shade than that of annual crops such as cereals grown in silvoarable systems (Moreno et al., 2007a, b; Moreno, 2008), except for N2 fixing species (Carranca et al., 2015). Furthermore, grass under the tree cover can have a longer growing season (Puerto et al., 1990) and forage quality can be improved under tree canopies (Cubera et al., 2009). Therefore, silvopastoral systems might support a higher tree density than silvoarable systems (Benavides et al., 2009; Devkota et al., 2009), resulting in higher C stocks in the tree biomass (> $35 \mathrm{Mg} \mathrm{C} \mathrm{ha}^{-1}$ in this case).

\subsection{Carbon storage in the tree biomass}

The $\mathrm{C}$ stock in the tree biomass in the young plantations was negligible but, in the old plantations, $\mathrm{C}$ storage was greater in the tree biomass than in the soil (Fig. 5). The C accumulation rate in the tree biomass was higher in the old plantations than in young plantations. This is explained by the much higher total leaf area of old trees compared to very young trees and, therefore, by a higher photosynthesis capacity (Stephenson et al., 2014). However, estimates of the tree root biomass may be underestimated by the forest allometrics used. The architecture of agroforestry trees is different from forest trees owing to a lower intraspecific competition and to pruning. Moreover, agroforestry trees have been shown to be very deep rooted owing to soil tillage and to competition with intercrops (Mulia and Dupraz, 2006; Cardinael et al., 2015a). 
Carbon stock in the tree biomass is not usually considered as a long-term $\mathrm{C}$ sink in the same way as the SOC stock but the residence time of $\mathrm{C}$ in the harvested biomass depends on the fate of wood products and can be as long as many decades for timber wood (Profft et al., 2009; Bauhus et al., 2010), which was the case for the trees grown at the sites studied. Branches could be used as a substitute for fossil fuel to produce energy (Kürsten, 2000; Cardinael et al., 2012) or be returned to the soil as ramial chipped wood amendments (Barthès et al., 2010).

\section{Conclusion}

This study showed the potential of agroforestry systems to increase carbon stock in both the soil and tree biomass under different pedo-climatic conditions in France. The sampling protocol evaluated the spatial distribution of SOC stock and the results showed that it could be simplified for future studies. SOC stocks accumulated mainly in the tree rows and mainly in the top $30 \mathrm{~cm}$ of soil, but at deeper soil layers in two silvoarable sites, as well. Further studies are required to gain a better assessment of the effect of agroforestry on deep SOC stock. Allometric equations should be developed for trees grown in temperate agroforestry systems to reduce the uncertainty of tree root biomass estimates. Very old sites (> 40 years old) were under-represented in our dataset and long-term experimental agroforestry sites are required to assess the effect of trees on soil carbon over long periods.

\section{Acknowledgments}

This study was financed by the French Environment and Energy Management Agency (ADEME), following a call for proposals as part of the REACCTIF program (Research on Climate Change Mitigation in Agriculture and Forestry). This study was part of the funded 
project AGRIPSOL (Agroforestry for Soil Protection), coordinated by Agroof. Rémi Cardinael was also funded by La Fondation de France. Two anonymous reviewers provided many excellent comments that improved the quality of this manuscript. We are very grateful to the farmers who allowed us to take samples in their fields and to Eric Villeneuve (INRA) for his help at the Theix site. We should also like to thank Daniel Billou (UPMC), Manon Villeneuve (IRD), Patricia Mahafaka and Clément Renoir for their help in the field and in the laboratory.

\section{References}

Albrecht, A., Kandji, S.T., 2003. Carbon sequestration in tropical agroforestry systems. Agric. Ecosyst. Environ. 99, 15-27.

Amundson, R., 2001. The carbon budget in soils. Annu. Rev. Earth Planet. Sci. 29, 535-562.

Angers, D.A., Arrouays, D., Saby, N.P.A., Walter, C., 2011. Estimating and mapping the carbon saturation deficit of French agricultural topsoils. Soil Use Manag. 27, 448-452.

Arrouays, D., Balesdent, J., Jayet, P.A., Soussana, J.-F., Stengel, P., 2002. Contribution à la lutte contre l'effet de serre. Stocker du carbone dans les sols agricoles de France? Expertise Scientifique Collective, Synthèse du rapport. INRA, Paris.

Arrouays, D., Deslais, W., Badeau, V., 2001. The carbon content of topsoil and its geographical distribution in France. Soil Use Manag. 17, 7-11.

Bambrick, A.D., Whalen, J.K., Bradley, R.L., Cogliastro, A., Gordon, A.M., Olivier, A., Thevathasan, N. V, 2010. Spatial heterogeneity of soil organic carbon in tree-based intercropping systems in Quebec and Ontario, Canada. Agrofor. Syst. 79, 343-353.

Barthès, B.G., Manlay, R.J., Porte, O., 2010. Effets de l'apport de bois raméal sur la plante et le sol : une revue des résultats expérimentaux. Cah. Agric. 19, 280-287. 
Bauhus, J., van der Meer, P., Kanninen, M., 2010. Ecosystem Goods and Services from Plantation Forests. Earthscan, London, UK.

Benavides, R., Douglas, G.B., Osoro, K., 2009. Silvopastoralism in New Zealand: Review of effects of evergreen and deciduous trees on pasture dynamics. Agrofor. Syst. 76, 327-350.

Cairns, M.A., Brown, S., Helmer, E.H., Baumgardner, G.A., 1997. Root biomass allocation in the World's upland forests. Oecologia 111, 1-11.

Cardinael, R., Mao, Z., Prieto, I., Stokes, A., Dupraz, C., Kim, J.H., Jourdan, C., 2015a. Competition with winter crops induces deeper rooting of walnut trees in a Mediterranean alley cropping agroforestry system. Plant Soil 391, 219-235.

Cardinael, R., Chevallier, T., Barthès, B.G., Saby, N.P.., Parent, T., Dupraz, C., Bernoux, M., Chenu, C., 2015b. Impact of alley cropping agroforestry on stocks, forms and spatial distribution of soil organic carbon - A case study in a Mediterranean context. Geoderma 259-260, 288-299.

Cardinael, R., Thevathasan, N., Gordon, A., Clinch, R., Mohammed, I., Sidders, D., 2012. Growing woody biomass for bioenergy in a tree-based intercropping system in southern Ontario, Canada. Agrofor. Syst. 86, 279-286.

Carranca, C., Castro, I. V., Figueiredo, N., Redondo, R., Rodrigues, A.R.F., Saraiva, I., Maricato, R., Madeira, M.A. V, 2015. Influence of tree canopy on N2 fixation by pasture legumes and soil rhizobial abundance in Mediterranean oak woodlands. Sci. Total Environ. 506-507, 86-94.

Chave, J., Coomes, D., Jansen, S., Lewis, S.L., Swenson, N.G., Zanne, A.E., 2009. Towards a worldwide wood economics spectrum. Ecol. Lett. 12, 351-66.

Chenu, C., Klumpp, K., Bispo, A., Angers, D., Colnenne, C., Metay, A., 2014. Stocker du carbone dans les sols agricoles: évaluation de leviers d'action pour la France. Innov. 
Agron. 37, 23-37.

634

635

636

637

638

639

640

641

642

643

644

645

646

647

648

649

650

651

652

653

654

655

656

Conant, R.T., Paustian, K., Elliott, E.T., 2001. Grassland management and conversion into grassland: effects on soil carbon. Ecol. Appl. 11, 343-355.

Constantin, J., Mary, B., Laurent, F., Aubrion, G., Fontaine, A., Kerveillant, P., Beaudoin, N., 2010. Effects of catch crops, no till and reduced nitrogen fertilization on nitrogen leaching and balance in three long-term experiments. Agric. Ecosyst. Environ. 135, 268-278.

Cubera, E., Nunes, J.M., Madeira, M., Gazarini, L., 2009. Influence of Quercus ilex trees on herbaceous production and nutrient concentrations in southern Portugal. J. Plant Nutr. Soil Sci. $172,565-571$.

Devkota, N.R., Kemp, P.D., Hodgson, J., Valentine, I., Jaya, I.K.D., 2009. Relationship between tree canopy height and the production of pasture species in a silvopastoral system based on alder trees. Agrofor. Syst. 76, 363-374.

Dimassi, B., Cohan, J.-P., Labreuche, J., Mary, B., 2013. Changes in soil carbon and nitrogen following tillage conversion in a long-term experiment in Northern France. Agric. Ecosyst. Environ. 169, 12-20.

Dube, F., Espinosa, M., Stolpe, N.B., Zagal, E., Thevathasan, N. V., Gordon, A.M., 2012. Productivity and carbon storage in silvopastoral systems with Pinus ponderosa and Trifolium spp., plantations and pasture on an Andisol in Patagonia, Chile. Agrofor. Syst. $86,113-128$.

Dufour, L., Metay, A., Talbot, G., Dupraz, C., 2013. Assessing Light Competition for Cereal Production in Temperate Agroforestry Systems using Experimentation and Crop Modelling. J. Agron. Crop Sci.

Ellert, B.H., Bettany, J.R., 1995. Calculation of organic matter and nutrients stored in soils under contrasting management regimes. Can. J. Soil Sci. 75, 529-538. 
Ellert, B.H., Janzen, H.H., Entz, T., 2002. Assessment of a method to measure temporal change in soil carbon storage. Soil Sci. Soc. Am. J. 66, 1687-1695.

Fontaine, S., Bardoux, G., Abbadie, L., Mariotti, A., 2004. Carbon input to soil may decrease soil carbon content. Ecol. Lett. 7, 314-320.

Fontaine, S., Barot, S., Barré, P., Bdioui, N., Mary, B., Rumpel, C., 2007. Stability of organic carbon in deep soil layers controlled by fresh carbon supply. Nature 450, 277-281.

Freibauer, A., Rounsevell, M.D.A., Smith, P., Verhagen, J., 2004. Carbon sequestration in the agricultural soils of Europe. Geoderma 122, 1-23.

Germon, A., Cardinael, R., Prieto, I., Mao, Z., Kim, J.H., Stokes, A., Dupraz, C., Laclau, J.-P., Jourdan, C., 2016. Unexpected phenology and lifespan of shallow and deep fine roots of walnut trees grown in a silvoarable Mediterranean agroforestry system. Plant Soil 401, $409-426$.

Haile, S.G., Nair, V.D., Nair, P.K.R., 2010. Contribution of trees to carbon storage in soils of silvopastoral systems in Florida, USA. Glob. Chang. Biol. 16, 427-438.

Harris, D., Horwath, W.R., Van Kessel, C., 2001. Acid fumigation of soils to remove carbonates prior to total organic carbon or carbon-13 isotopic analysis. Soil Sci. Soc. Am. J. 65, 18531856.

Hassink, J., 1997. The capacity of soils to preserve organic C and $\mathrm{N}$ by their association with clay and silt particles. Plant Soil 191, 77-87.

Houghton, R.A., 2007. Balancing the global carbon budget. Annu. Rev. Earth Planet. Sci. 35, $313-347$.

Howlett, D.S., Moreno, G., Mosquera Losada, M.R., Nair, P.K.R., Nair, V.D., 2011. Soil carbon storage as influenced by tree cover in the Dehesa cork oak silvopasture of central-western Spain. J. Environ. Monit. 13, 1897-904. 
IUSS Working Group WRB, 2007. World Reference Base for Soil Resources 2006, first update 2007. World Soil Resources Reports No. 103. FAO, Rome.

Janzen, H.H., 2006. The soil carbon dilemma: Shall we hoard it or use it? Soil Biol. Biochem. $38,419-424$.

Kim, D.-G., Kirschbaum, M.U.F., Beedy, T.L., 2016. Carbon sequestration and net emissions of $\mathrm{CH} 4$ and $\mathrm{N} 2 \mathrm{O}$ under agroforestry: Synthesizing available data and suggestions for future studies. Agric. Ecosyst. Environ. 226, 65-78.

Kürsten, E., 2000. Fuelwood production in agroforestry systems for sustainable land use and CO2-mitigation. Ecol. Eng. 16, S69-S72.

Lal, R., 2004a. Soil carbon sequestration to mitigate climate change. Geoderma 123, 1-22.

Lal, R., 2004b. Soil carbon sequestration impacts on global climate change and food security. Science 304, 1623-1627.

Lamlom, S.H., Savidge, R.H., 2003. A reassessment of carbon content in wood: variation within and between 41 North American species. Biomass and Bioenergy 25, 381-388.

Lange, M., Eisenhauer, N., Sierra, C.A., Bessler, H., Engels, C., Griffiths, R.I., MelladoVázquez, P.G., Malik, A.A., Roy, J., Scheu, S., Steinbeiss, S., Thomson, B.C., Trumbore, S.E., Gleixner, G., 2015. Plant diversity increases soil microbial activity and soil carbon storage. Nat. Commun. 6, 6707.

Le Quéré, C., Peters, G.P., Andres, R.J., Andrew, R.M., Boden, T., Ciais, P., Friedlingstein, P., Houghton, R.A., Marland, G., Moriarty, R., Sitch, S., Tans, P., Arneth, A., Arvanitis, A., Bakker, D.C.E., Bopp, L., Canadell, J.G., Chini, L.P., Doney, S.C., Harper, A., Harris, I., House, J.I., Jain, A.K., Jones, S.D., Kato, E., Keeling, R.F., Klein Goldewijk, K., Körtzinger, A., Koven, C., Lefèvre, N., Omar, A., Ono, T., Park, G.-H., Pfeil, B., Poulter, B., Raupach, M.R., Regnier, P., Rödenbeck, C., Saito, S., Schwinger, J., Segschneider, J., 
Stocker, B.D., Tilbrook, B., van Heuven, S., Viovy, N., Wanninkhof, R., Wiltshire, A., Zaehle, S., Yue, C., 2014. Global carbon budget 2014. Earth Syst. Sci. Data Discuss. 7, $521-610$.

Levillain, J., Thongo M’Bou, A., Deleporte, P., Saint-André, L., Jourdan, C., 2011. Is the simple auger coring method reliable for below-ground standing biomass estimation in Eucalyptus forest plantations? Ann. Bot. 108, 221-230.

Lorenz, K., Lal, R., 2014. Soil organic carbon sequestration in agroforestry systems. A review. Agron. Sustain. Dev. 34, 443-454.

Luo, Z., Wang, E., Sun, O.J., 2010. Can no-tillage stimulate carbon sequestration in agricultural soils? A meta-analysis of paired experiments. Agric. Ecosyst. Environ. 139, 224-231.

Marquard, E., Weigelt, A., Temperton, V.M., Roscher, C., Schumacher, J., Buchmann, N., Fischer, M., Weisser, W.W., Schmid, B., 2009. Plant species richness and functional composition drive overyielding in a six-year grassland experiment. Ecology 90, 32903302.

Martin, M.P., Wattenbach, M., Smith, P., Meersmans, J., Jolivet, C., Boulonne, L., Arrouays, D., 2011. Spatial distribution of soil organic carbon stocks in France. Biogeosciences 8, $1053-1065$.

Moreno, G., 2008. Response of understorey forage to multiple tree effects in Iberian dehesas. Agric. Ecosyst. Environ. 123, 239-244.

Moreno, G., Obrador, J.J., García, A., 2007a. Impact of evergreen oaks on soil fertility and crop production in intercropped dehesas. Agric. Ecosyst. Environ. 119, 270-280.

Moreno, G., Obrador, J.J., García, E., Cubera, E., Montero, M.J., Pulido, F., Dupraz, C., 2007b. Driving competitive and facilitative interactions in oak dehesas through management practices. Agrofor. Syst. 70, 25-40. 
Mosquera Losada, M.R., Freese, D., Rigueiro-Rodríguez, A., 2011. Carbon Sequestration in European Agroforestry Systems, in: Kumar, B.M., Nair, P.K.R. (Eds.), Carbon Sequestration Potential of Agroforestry Systems. Springer Netherlands, pp. 43-59.

Mulia, R., Dupraz, C., 2006. Unusual fine root distributions of two deciduous tree species in southern France: What consequences for modelling of tree root dynamics? Plant Soil 281, $71-85$.

Nair, P.K., 1993. An introduction to agroforestry. Kluwer, Dordrecht, The Netherlands.

Oelbermann, M., Voroney, R.P., Thevathasan, N. V., Gordon, A.M., Kass, D.C.L., Schlönvoigt, A.M., 2006. Soil carbon dynamics and residue stabilization in a Costa Rican and southern Canadian alley cropping system. Agrofor. Syst. 68, 27-36.

Paustian, K., Andrén, O., Janzen, H., Lal, R., Smith, P., Tian, G., Tiessen, H., Van Noordwijk, M., Woomer, P., 1997. Agricultural soils as a sink to mitigate CO2 emissions. Soil Use Manag. 13, 230-244.

Peichl, M., Thevathasan, N. V, Gordon, A.M., Huss, J., Abohassan, R.A., 2006. Carbon sequestration potentials in temperate tree-based intercropping systems, southern Ontario, Canada. Agrofor. Syst. 66, 243-257.

Pellerin, S., Bamière, L., Angers, D., Béline, F., Benoît, M., Butault, J.P., Chenu, C., ColnenneDavid, C., De Cara, S., Delame, N., Doreau, M., Dupraz, P., Faverdin, P., Garcia-Launay, F., Hassouna, M., Hénault, C., Jeuffroy, M.., Klumpp, K., Metay, A., Moran, D., Recous, S., Samson, E., Savini, I., Pardon, L., 2013. How can French agriculture contribute to reducing greenhouse gas emissions? Abatement potential and cost of ten technical measures. Synopsis of the study report, INRA, Paris (France).

Picard, N., Saint-André, L., Henry, M., 2012. Manual for building tree volume and biomass allometric equations. From field measurement to prediction, CIRAD. ed. FAO. 
Pinheiro, J., Bates, D., DebRoy, S., Sarkar, D., R Development Core Team, 2013. nlme: Linear and Nonlinear Mixed Effects Models. R package version 3.1-111.

Poeplau, C., Don, A., 2015. Carbon sequestration in agricultural soils via cultivation of cover crops - A meta-analysis. Agric. Ecosyst. Environ. 200, 33-41.

Prieto, I., Violle, C., Barre, P., Durand, J., Ghesquiere, M., Litrico, I., 2015. Complementary effects of species and genetic diversity on productivity and stability of sown grasslands. Nat. Plants $1-5$.

Profft, I., Mund, M., Weber, G.-E., Weller, E., Schulze, E.-D., 2009. Forest management and carbon sequestration in wood products. Eur. J. For. Res. 128, 399-413.

Puerto, A., Rico, M., Matias, M., Garcia, J., 1990. Variation in structure and diversity in Mediterranean grasslands related to trophic status and grazing intensity. J. Veg. Sci. 1, $445-452$.

R Development Core Team, 2013. R: A language and environment for statistical computing.

Rasse, D.P., Rumpel, C., Dignac, M.F., 2005. Is soil carbon mostly root carbon? Mechanisms for a specific stabilisation. Plant Soil 269, 341-356.

Rhoades, C.C., 1997. Single-tree influences on soil properties in agroforestry: lessons from natural forest and savanna ecosystems. Agrofor. Syst. 35, 71-94.

Smith, P., 2004. Carbon sequestration in croplands: the potential in Europe and the global context. Eur. J. Agron. 20, 229-236.

Soussana, J.-F., Loiseau, P., Vuichard, N., Ceschia, E., Balesdent, J., Chevallier, T., Arrouays, D., 2004. Carbon cycling and sequestration opportunities in temperate grasslands. Soil Use Manag. 20, 219-230.

Steinbeiss, S., Beßler, H., Engels, C., Temperton, V.M., Buchmann, N., Roscher, C., Kreutziger, Y., Baade, J., Habekost, M., Gleixner, G., 2008. Plant diversity positively 
affects short-term soil carbon storage in experimental grasslands. Glob. Chang. Biol. 14, $2937-2949$.

Stephenson, N.L., Das, A.J., Condit, R., Russo, S.E., Baker, P.J., Beckman, N.G., Coomes, D.A., Lines, E.R., Morris, W.K., Rüger, N., Álvarez, E., Blundo, C., Bunyavejchewin, S., Chuyong, G., Davies, S.J., Duque, Á., Ewango, C.N., Flores, O., Franklin, J.F., Grau, H.R., Hao, Z., Harmon, M.E., Hubbell, S.P., Kenfack, D., Lin, Y., Makana, J.-R., Malizia, A., Malizia, L.R., Pabst, R.J., Pongpattananurak, N., Su, S.-H., Sun, I.-F., Tan, S., Thomas, D., van Mantgem, P.J., Wang, X., Wiser, S.K., Zavala, M.A., 2014. Rate of tree carbon accumulation increases continuously with tree size. Nature 507, 90-93.

Tilman, D., Reich, P.B., Knops, J., Wedin, D., Mielke, T., Lehman, C., 2001. Diversity and productivity in a long-term grassland experiment. Science $294,843-845$.

Upson, M.A., Burgess, P.J., 2013. Soil organic carbon and root distribution in a temperate arable agroforestry system. Plant Soil 373, 43-58.

Virto, I., Barré, P., Burlot, A., Chenu, C., 2012. Carbon input differences as the main factor explaining the variability in soil organic $\mathrm{C}$ storage in no-tilled compared to inversion tilled agrosystems. Biogeochemistry 108, 17-26.

Wotherspoon, A., Thevathasan, N. V., Gordon, A.M., Voroney, R.P., 2014. Carbon sequestration potential of five tree species in a 25 -year-old temperate tree-based intercropping system in southern Ontario, Canada. Agrofor. Syst. 88, 631-643.

Zanne, A.E., Lopez-Gonzalez, G., Coomes, D.A., Llic, J., Jansen, J., Lewis, S.L., Miller, R.B., Swenson, N.G., Wiemann, M.C., Chave, J., 2009. Data from: Towards a worldwide wood economics spectrum. Dryad Digital Repository. http://dx.doi.org/10.5061/dryad.234. 
801 Table S1 ANOVA on the linear mixed-effects (LME) model for SOC content, bulk density and SOC stock in the agroforestry plots as a function

of depth, location (inter-row or tree row), distance to the closest tree, and interactions between these.

\begin{tabular}{|c|c|c|c|c|c|c|c|}
\hline \multirow[b]{2}{*}{ Site } & & \multicolumn{2}{|c|}{ Soil organic carbon content } & \multicolumn{2}{|c|}{ Bulk density } & \multicolumn{2}{|c|}{ Soil organic carbon stock } \\
\hline & & F-value & $\operatorname{Pr}(>\mathrm{F})$ & F-value & $\operatorname{Pr}(>\mathrm{F})$ & F-value & $\operatorname{Pr}(>\mathrm{F})$ \\
\hline \multirow{6}{*}{$\mathrm{CH}$} & Depth & 64.982 & $<0.0001$ & 10.956 & 0.0001 & 22.341 & $<0.0001$ \\
\hline & Location & 2.246 & 0.137 & 3.153 & 0.079 & 1.890 & 0.173 \\
\hline & Distance & 0.394 & 0.532 & 0.266 & 0.607 & 0.379 & 0.540 \\
\hline & Depth $\times$ Location & 8.078 & 0.0006 & 0.672 & 0.513 & 6.908 & 0.002 \\
\hline & Depth×Distance & 0.576 & 0.564 & 0.296 & 0.744 & 0.570 & 0.568 \\
\hline & Location $\times$ Distance & 0.227 & 0.635 & 0.226 & 0.636 & 0.472 & 0.494 \\
\hline \multirow{6}{*}{ ME } & Depth & 140.956 & $<0.0001$ & 20.473 & $<0.0001$ & 24.004 & $<0.0001$ \\
\hline & Location & 130.363 & $<0.0001$ & 78.246 & $<0.0001$ & 116.989 & $<0.0001$ \\
\hline & Distance & 0.012 & 0.911 & 7.257 & 0.008 & 0.016 & 0.900 \\
\hline & Depth $\times$ Location & 51.699 & $<0.0001$ & 15.888 & $<0.0001$ & 45.731 & $<0.0001$ \\
\hline & Depth×Distance & 1.627 & 0.202 & 1.910 & 0.154 & 2.895 & 0.063 \\
\hline & Location $\times$ Distance & 0.004 & 0.949 & 0.162 & 0.688 & 0.144 & 0.705 \\
\hline \multirow{6}{*}{ SJ } & Depth & 370.623 & $<0.0001$ & 7.285 & 0.0104 & 284.905 & $<0.0001$ \\
\hline & Location & 35.543 & $<0.0001$ & 0.356 & 0.554 & 33.719 & $<0.0001$ \\
\hline & Distance & 15.183 & 0.0004 & 0.691 & 0.411 & 8.827 & 0.005 \\
\hline & Depth $\times$ Location & 6.719 & 0.014 & 6.305 & 0.017 & 9.250 & 0.004 \\
\hline & Depth×Distance & 4.101 & 0.0501 & 7.985 & 0.008 & 10.264 & 0.002 \\
\hline & Location $\times$ Distance & 0.987 & 0.327 & 1.534 & 0.223 & 0.728 & 0.399 \\
\hline \multirow{6}{*}{$\mathrm{VE}$} & Depth & 110.547 & $<0.0001$ & 39.920 & $<0.0001$ & 19.071 & $<0.0001$ \\
\hline & Location & 24.017 & $<0.0001$ & 5.956 & 0.016 & 23.272 & $<0.0001$ \\
\hline & Distance & 0.001 & 0.980 & 0.674 & 0.413 & 0.083 & 0.773 \\
\hline & Depth $\times$ Location & 2.801 & 0.019 & 1.998 & 0.082 & 2.243 & 0.053 \\
\hline & Depth×Distance & 0.086 & 0.994 & 0.917 & 0.472 & 0.151 & 0.980 \\
\hline & Location $\times$ Distance & 0.278 & 0.599 & 0.095 & 0.758 & 0.075 & 0.785 \\
\hline \multirow{6}{*}{$\mathrm{RE}$} & Depth & 703.719 & $<0.0001$ & 391.32 & $<0.0001$ & 723.666 & $<0.0001$ \\
\hline & Location & 223.367 & $<0.0001$ & 23.90 & $<0.0001$ & 66.935 & $<0.0001$ \\
\hline & Distance & 2.229 & 0.1387 & 2.12 & 0.1491 & 2.353 & 0.1283 \\
\hline & Depth $\times$ Location & 272.736 & $<0.0001$ & 10.04 & $<0.0001$ & 68.377 & $<0.0001$ \\
\hline & Depth×Distance & 2.338 & 0.0173 & 0.68 & 0.7137 & 1.775 & 0.0784 \\
\hline & Location $\times$ Distance & 4.425 & 0.0380 & 1.25 & 0.2666 & 3.285 & 0.0731 \\
\hline
\end{tabular}




\begin{tabular}{|c|c|c|c|c|c|c|c|}
\hline \multirow{6}{*}{$\mathrm{TH}$} & Depth & 89.206 & $<0.0001$ & 2.739 & 0.033 & 59.624 & $<0.0001$ \\
\hline & Location & 0.040 & 0.842 & 0.577 & 0.449 & 0.032 & 0.859 \\
\hline & Distance & 1.511 & 0.222 & 6.966 & 0.010 & 0.446 & 0.506 \\
\hline & Depth $\times$ Location & 0.673 & 0.612 & 0.817 & 0.517 & 0.622 & 0.648 \\
\hline & Depth×Distance & 0.225 & 0.924 & 0.750 & 0.560 & 0.341 & 0.850 \\
\hline & Location $\times$ Distance & 0.235 & 0.629 & 1.663 & 0.200 & 0.001 & 0.975 \\
\hline
\end{tabular}

803 CH: Châteaudun, ME: Melle, SJ: Saint-Jean-d'Angély, VE: Vézénobres, RE: Restinclières, TH: Theix. 
805

806

807

808

809

810

811

812

813

814

815

816

817

818

819

820

821

822

823

824

825

826

827

828

829

830

831 